\title{
Call it home: Mesolithic dwellings in the Ebro Basin (NE Spain)
}

\author{
Rafael Domingo, Marta Alcolea, Manuel Bea, Carlos Mazo, Lourdes Montes, Jesús \\ Picazo, José M. ${ }^{a}$ Rodanés and Pilar Utrilla \\ Research group Primeros pobladores del Valle del Ebro \\ University of Zaragoza, Spain
}

\begin{abstract}
This paper summarises our knowledge of Mesolithic space management — which concerns the choice of the living place itself and the recognisable dwelling structures in the Middle Ebro Basin, where more than fifteen accurately dated Mesolithic sites have been found and excavated in the last several decades.

In the last forty years, the Ebro Basin has emerged as the most important area for the study of the Mesolithic and Early Neolithic period in the Iberian Peninsula. Dozens of recently excavated sites with hundreds of accurate radiocarbon dates offer a good panorama of the transition from traditional hunting-gathering strategies to the gradual incorporation of Neolithic innovations. Nevertheless, much remains unknown in wide areas across the basin due to poor conservation or mere research defaults, so there is still much work to do. For brevity and research tradition, this paper will be restricted to the Middle Ebro Basin.

The vast majority of documented Mesolithic sites throughout the basin occupy the frequent limestone, sandstone or conglomeratic rockshelters that proliferate in the ranges flanking the north and the lower flat areas in the south. There, natural "roofed" refuges are scarce, and prehistoric groups inhabited open-air campsites. Archaeological surveys are difficult to conduct in these flat terrains due to high-scale Holocene erosive processes, which hamper our knowledge of the actual dwelling strategies in Mesolithic times. Across the basin, only one open-air site is known about compared to more than forty rockshelters. Of these, most share common elements: they are small, open to the rising sun and appear next to rivers or ravines, guaranteeing access to fresh water and control of potential game. Some show evidence of human presence from the Magdalenian times; others were in use in the Neolithic period and beyond. A common feature is the final prehistoric usage of funerary sites during the Chalcolithic period. Many sites are in close vicinity to one another, but due to the imprecision of our data, it is impossible to know with certainty whether different groups occupied them at the same time. Most habitual structures found in them are hearths, usually circled (or even paved) with local cobbles or slabs, but some space arrangements (rudimentary walls, postholes...) have been occasionally documented.
\end{abstract}

\section{Introduction}

The Ebro Basin is a wide natural region that occupies the NE area of the Iberian Peninsula. In its area of more than $80,000 \mathrm{sq}$. $\mathrm{km}$, a huge variety of different environments can be found - from the highest mountains of Southern Europe (the Pyrenees) to semi-desert plains filled with Holocene fluvial deposits around the central corridor. We find wet and forested regions in the NW part of the basin (thanks to an Atlantic-type climate) as well as dry territories to the SE, where annual rainfall does not reach $250 \mathrm{~mm}$ and the potential evapotranspiration surpasses $1200 \mathrm{~mm} /$ year - a classic example of an irregular Mediterranean climatic regime. The drainage network (Figure 1 ) is quite regular: most of the Ebro River's tributaries follow a regular N-S or S-N path, forming natural corridors from the central flat areas to the surrounding mountain ranges 
and allowing "easy" access to other regions beyond the basin. From a geological perspective (Garcia-Castellanos et al., 2003), the current basin was shaped by Alpine tectonic shifts, which pushed up the marginal mountain chains (the Pyrenees to the north, the Iberian Ranges to the south) and formed a sedimentary depression. During the Neogene period, a large endorheic basin occupied the central area, which became exoreic after the Late Miocene. The subsequent outflow to the Mediterranean Sea was followed by the growth of the Ebro River fluvial system, draining immense amounts of sediment to the sea and shaping the present-day landscape. This evolution formed a highly contrasted landscape (Peña-Monné et al., 2002): the central part of the basin is dominated by calcareous horizontal platforms that include abundant chert nodules that have been massively exploited and "exported" in prehistoric times (García-Simón and Domingo, 2016) and have been shaped by a profuse network of ravines. Large-scale erosive processes have deeply transformed the landscape in Holocene times: enormous quantities of sediment torn from the tops of hills and plateaus have filled the bottom of the ravines, creating flat-bottom valleys (locally known as vales). Occasionally, new incision processes have affected these vales, creating deep creeks. Thus, in the Middle Ebro Basin, it is difficult to find prehistoric open-air sites since the ancient terrain level is currently covered by thick sedimentary layers of up to $15 \mathrm{~m}$, as documented in the Neolithic site of Samitiel (Peña-Monné et al., 2005). The only known example, the Mesolithic campsite of Cabezo de la Cruz, was found during a public work project related to the opening of a new highway when massive terrain movements were carried out (Rodanés and Picazo, 2009; 2013).

Figure 1. Mesolithic sites at the Middle Ebro Basin (image: NASA). In white, studied sites. In grey, other sites cited in the text. The two main sites concentration areas (Arba de Biel and Matarraña) are signalled in blue.

The Mesolithic period is one of the best-known prehistoric periods in the Ebro Basin (Alday, 2006; Utrilla and Montes, 2009; Soto et al., 2015). In the last decades, the reconstructed cultural sequence (which was first drafted by Fortea, 1973) combines regional singularities and strong links with other neighbouring regions (namely, the northern Pyrenees and the Mediterranean coastal area): in the Early Holocene, the laminar Magdalenian tradition is still recognisable, but we can perceive stronger regionalisation in the industries (ca. 13500-10250 cal BP). The difficult characterisation of these ensembles (Soto et al., 2015) has provoked a multiplicity of denominations Sauveterrian, Azilian, Microlaminar — that denote their similarity to nearby assemblages. To ease their identification, we can call it Microlaminar Mesolithic. In the following millennia -and in several sites after the sedimentation of true sterile levels that lasted up to one thousand years-, a technological rupture can be seen throughout the Basin: the laminar tradition is no longer predominant, and most of the tools are carelessly knapped denticulates that appear to be linked to intense wood processing tasks (Alday, 2006) (Denticulate Mesolithic, ca. 10250-8800 cal BP). The last centuries before the appearance of Neolithic innovations is marked by the recovery of the laminar technology, which, in combination with the microburin technique, is employed to obtain massive quantities of small projectile points of geometric morphologies (Utrilla and Montes, 2009) (Geometric Mesolithic, ca. 8800-7600 cal BP). Dates offered to frame those industries must be seen as approximate: those cultural horizons do not appear synchronically along the Basin (Alday et al., 2017); table 1 details the radiocarbon dates (only those with a standard deviation $<100$ ) available for the studied ensemble.

\begin{tabular}{|l|l|l|l|l|l|l|}
\hline Period & Site & Lab. reference & Date & \pm & calBP & Reference \\
\hline
\end{tabular}




\begin{tabular}{|c|c|c|c|c|c|c|c|}
\hline GM & Valcervera & GrA-27876 & 6815 & 45 & 7580 & 7727 & (Montes et al., 2015) \\
\hline GM & Forcas II & Grn-22688 & 6900 & 45 & 7656 & 7843 & (Utrilla and Mazo, 2014) \\
\hline GM & Forcas II & Beta-60773 & 6940 & 90 & 7618 & 7941 & (Utrilla and Mazo, 2014) \\
\hline GM & Esplugón & Beta-306723 & 6950 & 50 & 7680 & 7925 & (Utrilla et al., 2016) \\
\hline GM & Ángel 2 & Beta-266112 & 6990 & 50 & 7705 & 7934 & (Domingo et al., 2010) \\
\hline GM & Valcervera & GrA-45783 & 6995 & 40 & 7727 & 7934 & (Montes et al., 2015) \\
\hline GM & Forcas II & Beta-290932 & 7000 & 40 & 7735 & 7935 & (Utrilla and Mazo, 2014) \\
\hline GM & Valcervera & GrA-45763 & 7035 & 45 & 7760 & 7960 & (Montes et al., 2015) \\
\hline GM & Costalena & MAMS-29828 & 7053 & 27 & 7838 & 7958 & Unpublished \\
\hline GM & Ángel 2 & Beta-286820 & 7120 & 50 & 7846 & 8021 & (Utrilla and Mazo, 2014) \\
\hline GM & Cabezo de la Cruz & GrN-29135 & 7150 & 70 & 7841 & 8160 & (Rodanés y Picazo, 2009) \\
\hline GM & Forcas II & Beta-250944 & 7150 & 40 & 7871 & 8031 & (Utrilla and Mazo, 2014) \\
\hline GM & Rambla Legunova & GrA-64001 & 7225 & 40 & 7966 & 8160 & (Montes et al., 2015) \\
\hline GM & Rambla Legunova & GrA-47886 & 7235 & 45 & 7970 & 8164 & (Montes et al., 2015) \\
\hline GM & Forcas II & GrN-22686 & 7240 & 40 & 7978 & 8163 & (Utrilla and Mazo, 2014) \\
\hline GM & Rambla Legunova & GrA-61768 & 7260 & 45 & 7983 & 8174 & (Montes et al., 2015) \\
\hline GM & Pontet & GrN-16313 & 7340 & 70 & 8012 & 8326 & (Mazo and Montes, 1992) \\
\hline GM & Pontet & D-AMS 020210 & 7341 & 32 & 8030 & 8283 & Unpublished \\
\hline GM & Baños & GrA-21550 & 7350 & 50 & 8028 & 8311 & (Utrilla and Rodanés, 2004) \\
\hline GM & Espantalobos & Beta-361624 & 7390 & 40 & 8055 & 8341 & (Montes et al., 2015) \\
\hline GM & Ángel 1 & GrA-27274 & 7435 & 45 & 8178 & 8357 & (Utrilla et al., 2009) \\
\hline GM & Baños & GrA-21551 & 7550 & 50 & 8206 & 8430 & (Utrilla and Rodanés, 2004) \\
\hline GM & Baños & GrN-24300 & 7570 & 100 & 8180 & 8560 & (Utrilla and Rodanés, 2004) \\
\hline GM & Botiquería & GrA-13265 & 7600 & 50 & 8335 & 8537 & (Barandiarán and Cava, 2000) \\
\hline GM & Esplugón & GrA-59632 & 7620 & 40 & 8365 & 8518 & (Utrilla et al., 2016) \\
\hline GM & Peña 14 & GrN-25094 & 7660 & 90 & 8224 & 8637 & (Montes et al., 2015) \\
\hline GM & Esplugón & GrA-59634 & 7715 & 45 & 8418 & 8584 & (Utrilla et al., 2016) \\
\hline $\mathrm{DM}$ & Baños & GrA-21552 & 7740 & 50 & 8420 & 8597 & (Utrilla and Rodanés, 2004) \\
\hline $\mathrm{DM}$ & Baños & GrN-24299 & 7840 & 100 & 8445 & 8984 & (Utrilla and Rodanés, 2004) \\
\hline $\mathrm{DM}$ & Esplugón & Beta-306725 & 7860 & 40 & 8546 & 8933 & (Utrilla et al., 2016) \\
\hline DM & Espantalobos & Beta-361625 & 7900 & 50 & 8593 & 8978 & (Montes et al., 2015) \\
\hline DM & Pontet & D-AMS 020211 & 7941 & 65 & 8609 & 8030 & Unpublished \\
\hline $\mathrm{DM}$ & Ángel 1 & GrA-27278 & 7955 & 45 & 8647 & 8988 & (Utrilla et al., 2009) \\
\hline $\mathrm{DM}$ & Peña 14 & GrN-25998 & 8000 & 90 & 8598 & 9112 & (Montes et al., 2015) \\
\hline $\mathrm{DM}$ & Peña 14 & GrN-25999 & 8000 & 80 & 8605 & 9077 & (Montes et al., 2015) \\
\hline $\mathrm{DM}$ & Esplugón & GrA-59633 & 8015 & 45 & 8716 & 9020 & (Utrilla et al., 2016) \\
\hline $\mathrm{DM}$ & Baños & GrA-21556 & 8040 & 50 & 8719 & 9086 & (Utrilla and Rodanés, 2004) \\
\hline $\mathrm{DM}$ & Legunova & GrA-24292 & 8200 & 50 & 9015 & 9300 & (Montes et al., 2015) \\
\hline DM & Legunova & GrA-22086 & 8250 & 60 & 9032 & 9417 & (Montes et al., 2015) \\
\hline $\mathrm{DM}$ & Ángel 2 & GrA-22836 & 8310 & 60 & 9132 & 9466 & (Utrilla et al., 2009) \\
\hline $\mathrm{DM}$ & Esplugón & Beta 306722 & 8380 & 40 & 9299 & 9485 & (Utrilla et al., 2016) \\
\hline $\mathrm{DM}$ & Ángel 1 & GrA-22826 & 8390 & 60 & 9275 & 9526 & (Utrilla et al., 2009) \\
\hline $\mathrm{DM}$ & Forcas II & Beta-59997/CAMS-5354 & 8650 & 70 & 9520 & 9887 & (Utrilla and Mazo, 2014) \\
\hline $\mathrm{DM}$ & Legunova & GrA-24294 & 8800 & 40 & 9666 & 10135 & (Montes et al., 2015) \\
\hline MLM & Forcas I & GrN-17785 & 9715 & 75 & 10785 & 11251 & (Utrilla and Mazo, 2014) \\
\hline MLM & Peña 14 & GrN-26000 & 10630 & 100 & 12237 & 12739 & (Montes et al., 2015) \\
\hline
\end{tabular}

Table 1. Radiocarbon dates of the Mesolithic sites from the Middle Ebro Basin (GM: Geometric Mesolithic; DM: Denticulate Mesolithic; MLM: Microlaminar Mesolithic).

The Mesolithic period is the first moment when a dense network of sites can be documented throughout the basin despite the thus-far empty territories, in which linking the well-established local and regional grids has been difficult for us. Many of those sites had been occupied since the Late Magdalenian period, such as Atxoste, Martinarri, Legunova or Forcas-I, but in many of them, the Microlaminar period shows the beginning of human occupations, such as in Mendandia or Peña-14 (Soto et al., 2015). These ancient human visits appear to be more frequent in the central and northwestern parts of the Basin, while in other areas such as the Bajo Aragón, most of the sites were occupied later, from the Denticulate period onwards. For brevity and due to research tradition, this paper will discuss only the main features of the Mesolithic sites located in the Middle Ebro region. 


\section{The sites: macro- and microspatial features}

The sites location can be circumscribed to two main environments: the footsteps of the middle-mountain ranges (the Pre-Pyrenees to the North and the Iberian Ranges to the south) and the lowlands of the Central Depression. The first environment was built from rockshelters in relatively humid environments next to rivers. The second group comprises the only known open-air site as well as small sandstone rockshelters in drier and flatter territories. From west to east (Figure 1; radiocarbon dates in Table 1), the Prepyrenean Ranges include the Arba de Biel Basin (Legunova, Peña-14, Rambla, Valcervera and Paco-Pons) (Montes et al., 2016b), Esplugón in the Guarga Basin (Utrilla et al., 2016) and the Forcas-I and Forcas-II sites next to the Ésera River (Utrilla and Mazo, 2014). Slightly to the south of this mountainous belt, we find Espantalobos, a small rockshelter located in a plain territory (Montes et al., 2015). In the right margin of the Ebro river, from west to east, we discuss the only true open-air site of the Basin, Cabezo de la Cruz (Rodanés y Picazo, 2013), and in transitional territories between the real plains and the Ranges, the sites of Los Baños in the Martín River (Utrilla and Rodanés, 2004), Plano del Pulido in the Guadalope Basin (Utrilla y Bea, 2012), and Botiquería (Barandiarán, 1978), Secans (Rodanés et al., 1996), Pontet (Mazo and Montes, 1992) and Costalena (Barandiarán and Cava, 1989) in the Matarraña-Algás Basin. Upstream in the Guadalope River, we find the sites of Ángel 1 and Ángel 2 in the heart of the Iberian Ranges (Utrilla et al., 2003). Table 2 details the main locational data of these sites.

\begin{tabular}{|c|c|c|c|c|c|c|}
\hline \multirow[t]{2}{*}{ Site } & \multirow[t]{2}{*}{ River basin } & \multirow[t]{2}{*}{ Environmental area } & \multirow{2}{*}{$\begin{array}{c}\text { Altitude } \\
\text { asl }\end{array}$} & \multicolumn{2}{|c|}{$\begin{array}{l}\text { Distance closest } \\
\text { water course }(\mathrm{m})\end{array}$} & \multirow[t]{2}{*}{ Orientation } \\
\hline & & & & Horizontal & Vertical & \\
\hline Peña-14 & \multirow{4}{*}{ Arba de Biel } & \multirow{5}{*}{$\begin{array}{l}\text { Footsteps of middle } \\
\text { mountain ranges }\end{array}$} & 750 & 160 & 10 & $E$ \\
\hline Legunova & & & 700 & 5 & 2 & $\mathrm{E}$ \\
\hline Rambla & & & 695 & 70 & 5 & $E$ \\
\hline Valcervera & & & 655 & 70 & 5 & $E$ \\
\hline Esplugón & Guarga (Gállego) & & 805 & 300 & 20 & $\mathrm{~S}$ \\
\hline Espantalobos & Flumen (Cinca) & Dry lowlands & 500 & 850 & 20 & $E$ \\
\hline Forcas-I & \multirow{2}{*}{ Ésera (Cinca) } & \multirow{2}{*}{$\begin{array}{l}\text { Footsteps of middle } \\
\text { mountain ranges }\end{array}$} & 495 & 100 & 10 & W \\
\hline Forcas-II & & & 490 & 10 & 5 & $\mathrm{~N}$ \\
\hline Cabezo de la Cruz & Huerva & Dry lowlands & 428 & 300 & 20 & - \\
\hline Los Baños & Martín & Dry lowlands & 515 & 20 & 5 & $E$ \\
\hline Ángel 1 & \multirow{3}{*}{ Guadalope } & \multirow{2}{*}{$\begin{array}{l}\text { Footsteps of middle } \\
\text { mountain ranges }\end{array}$} & 655 & 30 & 5 & W \\
\hline Ángel 2 & & & 665 & 30 & 15 & SW \\
\hline Plano del Pulido & & \multirow{5}{*}{ Dry lowlands } & 240 & 1700 & 20 & $\mathrm{~S}$ \\
\hline Costalena & \multirow{4}{*}{$\begin{array}{l}\text { Matarrañal } \\
\text { Algás }\end{array}$} & & 215 & 150 & 10 & $\mathrm{~S}$ \\
\hline Botiquería dels Moros & & & 330 & 40 & 10 & $E$ \\
\hline Pontet & & & 285 & 175 & 10 & W \\
\hline Secans & & & 360 & 150 & 10 & $E$ \\
\hline
\end{tabular}

Table 2. Geographical features of the studied sites. Between parenthesis, main tributaries to the Ebro if the site is in a secondary river basin.

As previously mentioned, sixteen out of the seventeen Mesolithic sites known so far in the Middle Ebro Basin are rockshelters of different lithologies (mainly sandstones but also limestone and conglomerate): only Cabezo de la Cruz is a true open-air campsite, far from rocky outcrops. Nevertheless, we cannot discount the possibility that prehistoric groups had built open-air habitats next to the protection offered by the rockshelter cover, as proposed for the Magdalenian occupation at Molí del Salt (GarcíaDiez and Vaquero, 2015), where the main campsite could have been located next to the rocky outcrop. However, as far as we know, the Mesolithic hunter-gatherers frequently looked for a certain natural roofed protection. We must be aware that the findings of 
prehistoric dwellings are seriously conditioned by the series of factors previously quoted (Peña-Monné et al., 2005) and that our current knowledge is partial and heavily biased in favour of rockshelter-protected sites (Alday et al., 2017). Rodanés and Picazo (2013) annotate a series of open-air isolate findings in the lowlands of the Ebro Basin that can be dated to the Mesolithic times, although they lack accurate dates. In any case, we can be sure of at least one deliberate decision made by the Mesolithic people: they preferred rockshelters to caves, even in terrains where both were accessible. For example, the huge Chaves cave in the Prepyrenean area was intensely occupied in Magdalenian times (Utrilla and Montes, 2007) and again during the Early Neolithic period (Baldellou, 2011), when it became a sort of village with an advanced farming settlement and lifestyle. However, surprisingly, in Mesolithic times, such a favourable place (3,000 sq. $\mathrm{m}$ of habitable roofed area) appears to have been rejected by huntergatherer groups.

The sixteen dated (only Secans remains undated due to sedimentary processes that destroyed all organic elements) and recently excavated Mesolithic sites may suggest that the Middle Ebro Basin is a well-known territory. In contrast, massive areas completely lack archaeological remains dating back to that phase, and sites appear concentrated in selected spots. We have attempted to overcome the difficulty of evaluating the density of sites by narrowing the territory: Table 3 shows the site density of the hydrographical basins where they are located (taken as reference areas). We have obtained the average result of a site every $870 \mathrm{sq} . \mathrm{km}$, with small differences between the right and the left margin. Nevertheless, this general overview must be nuanced: frequently, the sites are concentred in smaller areas as a result of territorially focused research efforts. For example, the four sites from the Arba de Biel are barely $6 \mathrm{~km}$ apart in a territory less than 25 sq. $\mathrm{km}$ wide.

\begin{tabular}{|c|c|c|c|c|}
\hline Ebro River Margin & Hydrographical basin & Total $\mathrm{km}^{2}$ & Sites & $\mathrm{km}^{2} /$ site \\
\hline \multirow{4}{*}{ Left/North } & Arba de Biel & 2,249 & 4 & 750 \\
\cline { 2 - 5 } & Guarga & 450 & 1 & 450 \\
\cline { 2 - 5 } & Flumen & 1,429 & 1 & 1,429 \\
\cline { 2 - 5 } & Ésera & 1,535 & 2 & 767 \\
\cline { 2 - 5 } & Subtotal left & 5,663 & 8 & 809 \\
\hline \multirow{4}{*}{ Right/South } & Huerva & 1,020 & 1 & 1,020 \\
\cline { 2 - 5 } & Martín & 2,095 & 1 & 2,095 \\
\cline { 2 - 5 } & Guadalope & 3,890 & 3 & 1,296 \\
\cline { 2 - 5 } & Matarraña/Algás & 1,250 & 4 & 312 \\
\cline { 2 - 5 } & Subtotal right & 8,255 & 9 & 917 \\
\hline Total & - & 13,918 & $\mathbf{1 7}$ & $\mathbf{8 7 0}$ \\
\hline
\end{tabular}

Table 3. The studied sites vs. the surface of the hydrographical basins where they are located.

Strictly speaking, we could consider the sites' rock walls and roofs as (natural) structures that prehistoric groups selected and made into shelter themselves. Indeed, the process of choosing a dwelling space would have been meticulous, and many aspects (local topography, orientation, climate, etc.) would have been taken into account. As detailed in Table 2, most of the Mesolithic sites of the Middle Ebro Basin share common features concerning location: good orientation (twelve out of the sixteen sites featured rocks facing east or south; the open-air site of Cabezo de la Cruz is located at the feet of a SE-oriented slope (Figure 3a)); relative closeness to watercourses or springs (in most cases, less than $200 \mathrm{~m}$; at Espantalobos, there is a surge that could have been active in Mesolithic times, and in the case of Plano del Pulido, the meanders of the Guadalope River may have been closer to the site than currently). Concerning the 
habitable surface, some difficulties arise: erosion and human intervention have modified the ancient morphologies of the rockshelters. Additionally, we do not know if the dwelling areas were limited to the rock protection or if those groups spread out to the immediate surroundings: most of the archaeological sequences have been partially destroyed by the opening of roads or other modern structures (that, on the other hand, allowed them to be found). In any case, most Middle Ebro Basin Mesolithic rockshelters are far from being large (the well-known Cova Gran ("Big Cave") de Santa Linya in the eastern Ebro Basin (Mora et al., 2011) is almost the only example in the Basin of a very big rockshelter occupied in prehistoric times): the average size ranges from 10 to 20 metres wide and in most cases are less than 5 metres deep (Figures 2 and 3 ). Only Forcas-I and Forcas-II (Figure $2 \mathrm{~g}$ and $2 \mathrm{~h}$ ) could have hosted extremely large human groups, but they are not true "under-roof" rockshelters: the high conglomerate cliffs offer dubious protection to climate constraints and can be a danger due to falling rocks, to which we must add their poor orientations (to the west and north, respectively). Undoubtedly, in these last cases, prehistoric hunter-gatherers valued the sites' strategic location near the confluence of two mighty rivers and a narrow canyon, disregarding the poor dwelling conditions. Frequently, erosive processes shortened the roofs' depth, and currently, most rockshelters offer limited protection (Peña-Monné et al., 2005).

Figure 2. Mesolithic sites from the left margin of the Middle Ebro Basin: a) Peña-14; b) Rambla de Legunova; c) Valcervera; d) Legunova; e) Esplugón; f) Espantalobos; g) Forcas-I; h) Forcas-II.

Figure 3. Mesolithic sites from the right margin of the Middle Ebro Basin: a) Cabezo de la Cruz; b) Los Baños; c) Plano del Pulido; d) Ángel 1 and Ángel 2; e) Secans; f) Botiquería; g) Costalena; h) Pontet.

\section{Documented structures: space management}

Prehistoric hearths have been extensively studied in older contexts (namely, the Upper Palaeolithic; Olive and Taborin, 1989) and from several points of view (experimental archaeology, anthracology, thermal treatment of lithic elements, etc.). However, concerning their size and shape, there is a noteworthy lack of systematisation in the approaches (Fernández Ruiz, 2016) that mostly consist of qualitative descriptions. This situation is especially true for NE Iberia, where the most comprehensive study, a $\mathrm{PhD}$ dissertation (Fernández Ruiz, 2016), did not include any Mesolithic sites. If we focus on the Mesolithic era, most papers address "local" questions, focusing on situations such as the difficulties of identifying prehistoric hearths in areas without rocks, which cannot be applied to our study area (Sergant et al., 2006). While desirable, a systematic approach to the topic is difficult due to the noteworthy differences in the published data: some offer precise information that includes measurements and accurate descriptions, whereas others only describe qualitative features of the excavated structures. Frequently, charcoal has not been exhaustively recovered, with complete sampling only in the last several years. Previously, it was mainly collected for dating purposes, so in most cases, we cannot know what type of wood was burnt.

Two types of built structures can be recognised in the Ebro Basin Mesolithic sites: dwellings and hearths or combustion structures. Both are usually difficult to identify in the archaeological record. The most common ones are hearths. Frequently, they had been disused and dismantled in prehistoric times, and we only find circumstantial evidence of their existence (ashes, rubefacted soils, dispersed charcoal and charred bones or lithic elements, etc.). However, occasionally, they are still well conserved, usually as cobble circles. Even in this case, they reflect the moment of abandonment of the site and hence of all the structures within. Only two sites stand out from this 
panorama. The first is Cabezo de la Cruz (Rodanés and Picazo, 2013), which thus far is the only true Mesolithic open-air campsite excavated in the Ebro Basin. Although we suspect that some rockshelters may have been employed such as landmarks and that the main zone of their occupation could have been the annexed flat and uncovered area, this is not the case of Cabezo de la Cruz, a real open-air site far from any rocky relief. Second, Secans, where a stone wall-like structure forming a closed space under the paleochannel roof was recognised during the fieldwork (Rodanés et al., 1996), is the sole example we know of so far within the Mesolithic Ebro Basin ensemble. Occasionally, cylindrical hollows appearing in the sites have been interpreted as postholes, although ascertaining their possible structural function or the construction morphology is a daunting task. When available, the wood charcoal analysis offers interesting information concerning organic elements related to these structures dismantled or not - such as the firewood used in the case of hearths or the actual presence of wooden posts.

When available, we will discuss the archaeological remains' spatial distribution, although the particular features of the excavated Mesolithic sites limit the informative value of those data. Most have been severely affected by erosion or human intervention, and the fieldwork is far from being exhaustive in terms of the supposed site's prehistoric extension. Frequently, these remains are only lithic materials due to the poor preservation of organic elements.

\subsection{Dwelling structures}

As previously stated, Cabezo de la Cruz is in the transitional zone between the lower slopes of a tiny plateau (which is known as "Cabezo", a local term for these types of small aclinal reliefs) and the ancient fluvial terraces of the Huerva River. The documented structure found there was a hut floor whose main feature was a circular cut that affected both the substrate clays and the slope formation, creating a horizontal platform (Figure 4). It was almost 5 metres in diameter, with a perimeter of $15.5 \mathrm{~m}$ and a usable surface of at least $13 \mathrm{sq}$. m. The dip barely surpassed $20 \mathrm{~cm}$ (less than $4 \%$ ). Inside this space, an eccentrically circular hole was identified as the hearth, around which three postholes $(23,13$ and $8 \mathrm{~cm}$ in diameter, respectively) appeared to have accommodated the wooden supports of the hut (or tent). These postholes contained the remains of Aleppo pine posts (Pinus halepensis) (Badal, 2013), which was one of the few tree species in the central Ebro Depression that produced long and straight trunks suitable for a structural function in an otherwise sparsely forested landscape. Outside the main structure, a fourth posthole was interpreted as a different construction. Some carbonised wooden logs were found in a very poor conservation state (Figure 4, top right). The unique characteristics of these archaeological works made further studies impossible: the adjacent areas had already been carelessly excavated in previous interventions, but the Mesolithic campsite should not have been less than 35 sq. $\mathrm{m}$ wide. The material remains inside the structure were scarce (Figure 4, centre right), although near the hearth there was a singular concentration of backed bladelets and fire-affected chert fragments. The excavators believed that the site was dismantled neatly due to the poor condition of the material assemblage found.

Figure 4. The open-air site of Cabezo de la Cruz: general view, details (in the top right, the logs remains appear framed by arrows; please note that they fell towards the centre of the structure), floor scheme and reconstruction of the built structure (Rodanés and Picazo, 2013). 
At the small rockshelter at Secans, archaeologists identified a simple structure that completed the protection offered by the paleochannel: an irregular wall formed by loosely stacked blocks forming a closed area. Prehistoric occupants created a natural hollow formed by water streams that had eroded the marl stratum and the overlapping silt-clay layer. The hut adopted an oval shape contoured by the plinth of blocks, which could have been surmounted by a vegetal structure that reached the rockshelter roof. The enclosed area was small, barely 3,5 $\mathrm{m}$ along the rockshelter wall, and 2,5 $\mathrm{m}$ wide, with an inhabitable surface of approximately 8-10 sq. $\mathrm{m}$ (Figure 5). There were no hearths inside the hut, although some ash deposits were found, scattered on the ground or filling small hollows excavated in the marl base. Understandably, the lithic assemblage distribution (Figure 5f) shows denser concentrations in the inner part of the rockshelter, while towards the exterior areas, the quantity of remains per sq. $\mathrm{m}$ decreases.

Figure 5. The dwelling structure found at Secans: a) proposed reconstruction; b) and c) the stonewall during the archaeological work; d) a general view of the rockshelter; note its small size; e) floor scheme detailing the wall structure; f) lithic element density (Rodanés et al., 1996).

\subsection{Hearths}

By far, the most common structures found at the Ebro Basin Mesolithic sites are combustion areas: nevertheless, there is huge variability in the number of hearths at the sites as well as in their shapes and sizes. Occasionally, the structure itself has not been found, and only some remnants point to its ancient presence (rubefacted soils, fire-burst stones or ash deposits). The main data concerning the number of hearths per site, the size and presence of the surrounding blocks are presented in Table 4.

\begin{tabular}{|c|c|c|c|c|c|c|}
\hline Site (level) (period) & $\begin{array}{c}\text { Number of } \\
\text { hearths }\end{array}$ & $\begin{array}{l}\text { Surrounded } \\
\text { by blocks }\end{array}$ & $\begin{array}{c}\text { Non surrounded by } \\
\text { blocks }\end{array}$ & $\begin{array}{c}\text { Diameter (cm) } \\
\text { (average) }\end{array}$ & $\begin{array}{c}\text { Surface }\left(\mathrm{m}^{2}\right) \\
\text { (average) }\end{array}$ & $\begin{array}{r}\text { Blocks no. } \\
\text { (average) }\end{array}$ \\
\hline Ángel 2 (2b) (DM) & 1 & 1 & - & 140 & 1,54 & 11 \\
\hline Botiquería (2) (GM) & 2 & 2 & - & No data & No data & 7 \\
\hline Botiquería (4) (GM) & 8 & 5 & 3 & No data & No data & 7 \\
\hline $\begin{array}{l}\text { Cabezo de la Cruz } \\
\text { (GM) }\end{array}$ & 1 & - & 1 & 65 & 0,38 & - \\
\hline $\begin{array}{l}\text { Costalena (c gener) } \\
\text { (GM) }\end{array}$ & 1 & 1 & - & 110 & 1,1 & No data \\
\hline $\begin{array}{l}\text { Costalena (c sup) } \\
\text { (GM) }\end{array}$ & 3 & 3 & - & No data & 0,44 & No data \\
\hline Costalena (c3) (GM) & 7 & 7 & - & No data & 0,18 & No data \\
\hline $\begin{array}{l}\text { Espantalobos }(e-c) \\
\text { (DM-GM) }\end{array}$ & 6 & 3 & 3 & No data & No data & No data \\
\hline Forcas I (7) (MLM) & 1 & 1 & - & No data & No data & No data \\
\hline Forcas II (Ib) (DM) & 2 & 1 & 1 & 85 & 0,55 & 1 \\
\hline Forcas II (II) (GM) & 2 & 2 & - & No data & No data & No data \\
\hline Forcas II (IV) (GM) & 4 & 2 & 2 & 37 & 0,1 & No data \\
\hline Peña-14 (b) (DM) & 2 & 2 & - & 50 & 0,20 & 8 \\
\hline Pontet (e) (GM) & 3 & - & 3 & No data & No data & - \\
\hline Rambla (2) (GM) & 1 & 1 & - & 60 & 0,28 & 10 \\
\hline
\end{tabular}

Table 4. Available data of Mesolithic hearths from the Ebro Basin sites (in alphabetical order); MLM: Microlaminar Mesolithic; DM: Denticulate Mesolithic; GM: Geometric Mesolithic.

As seen in Table 4, there is large diversity in the recorded ensemble of sites. The number of hearths per level varies from eleven in Costalena or ten in Botiquería to only one in Ángel 2 or Rambla. Some of the recognised hearths still maintained a surrounding structure of cobbles or blocks that undoubtedly favoured their identification. 
The non-structured fireplaces still presented accumulations of ashes, and the surrounding sediment was rubefacted; burnt bones or lithic tools helped to confirm that they were actual hearths and not only the ash deposits that were the product of cleanings. Their sizes varied, although most are small or medium - less than $1 \mathrm{~m}$ in diameter. Large hearths such as those Forcas II Ib, Rambla 2 or Costalena $c$ genérico are rare. Significantly, those massive fireplaces are the only burning structures documented in the settlement in which they appear. In contrast, the abundant hearths in Costalena $c 3$ are among the smaller ones documented in the region. In Botiquería 4, Barandiarán (1978) did not offer data on their precise dimensions, but accurate drawings are presented (Figure 6). The eight recognised fireplaces appear to be small, barely $40 \mathrm{~cm}$ in diameter at the most.

Figure 6. Hearths from Botiquería level 4 (modified after Barandiarán, 1978).

In the four Mesolithic sites at the Arba de Biel area, the most interesting vestige is the hearth sequence documented at Rambla de Legunova (Montes et al., 2016), where no less than five different structures appear superimposed throughout more than one metre of stratigraphic sequence. The oldest one was built during the late Mesolithic occupation (level 2), while the other four are from the ancient Neolithic period. All of them were built from locally available sandstone blocks or river cobbles and boulders (the riverbed being less than $50 \mathrm{~m}$ away). The series of hearths occupy the centre of the conserved archaeological site, barely $1 \mathrm{~m}$ outside the deepest part of the taffoni. The presence of this series of hearths in virtually the same place can be explained by the reduced dimensions of the rockshelter: if one wants to build a fire, the site's topography almost forces one to choose that spot (see the small size of the taffoni in Figure 2b).

At Valcervera or Legunova, there are no clear remains of hearths, although their Mesolithic occupations have not been extensively excavated, while at Peña-14, the Denticulate level b (Figure 7) included two good examples of fireplaces that framed the most densely occupied area by its North and South extremes, although their contemporaneity is not clear: they appear at different depths. Unfortunately, this site only conserved a one-meter-wide archaeological sequence close to the rockshelter inner area, the rest having been destroyed by a road. The two hearths shared common features: they were small (less than $50 \mathrm{~cm}$ in diameter), circular-shaped and formed by an accumulation of sandstone blocks rather than riverbed pebbles or cobbles; the Arba de Biel River is less than $200 \mathrm{~m}$ away, but prehistoric groups preferred less durable but easily available sandstones. Concerning the firewood burnt at the Arba de Biel ensemble, the quantity of recovered charcoal remains is unequal, although some inferences can be obtained. Scots pine (Pinus tp. sylvestris) is the most consumed taxon throughout all different occupations, being the single wood species at Denticulate Mesolithic levels such as Peña-14 b or Legunova 1 and 2 and Geometric Mesolithic levels such as Valcervera $b$ and Rambla de Legunova 2 (which is the most thoroughly recovered charcoal assemblage). In deep contrast with the image offered by the pollen analysis (González-Sampériz, 2004), which shows a diverse environment where a large amount of broadleaved elements are represented, pine wood is the only consumed taxon by Mesolithic populations as fuel. This circumstance leads us to think of a clear preference for this particular type of wood by Mesolithic groups, although the motif remains unknown. Two charred acorns (Quercus sp.), undoubtedly gathered for food, were also documented at Rambla de Legunova. 
Figure 7. Hearth from level b, Denticulate Mesolithic, found at Peña-14. The employed blocks are local fragments of the sandstone paleochannel.

At Esplugón, where the archaeological fieldworks have affected a minimum part of the massive habitable space so far (barely eight out of more than fifty sq. m), no fire structure has been documented (Utrilla et al., 2016). Nevertheless, dispersed charcoal remains (identified as firewood) are abundant. As in the not-so-distant Arba de Biel Basin, Scots pine (Pinus tp. sylvestris) is the most consumed firewood. Pinewood exploitation oscillates between 85 and $100 \%$ depending on the level. Nevertheless, other woody species, such as oaks (Deciduous Quercus), shrubs (Juniperus sp., Evergreen Quercus and Rosaceae) and riparian taxa were also utilised at Esplugón (Utrilla et al., 2016).

The present state of Espantalobos (Montes et al., 2015), whose analysis is still unfinished, makes it difficult to imagine how the site looked in Mesolithic times. Erosive processes and human interventions have deeply modified the area: a water source that could have been active in prehistoric times had a narrow but deep ravine affecting the site integrity; additionally, local sandstone paleochannels, including the one designed for shelter by prehistoric human groups, have been profusely quarried. Several fireplaces have been documented at this site. In the Geometric Mesolithic level c, the two documented hearths appear related to the lithic element distribution along the occupation area (Figure 8): one of the concentrations was far denser than the other one, although the two hearths were similar in terms of size. More than 400 wood charcoal fragments appeared inside the big hearth belonging to the Denticulate Mesolithic transitional level (e), where an almost exclusive employment of junipers (Juniperus sp.) is documented (Alcolea et al., 2017). The best-conserved hearth from level c - the one related to the denser accumulation of lithic items - presented a simple structure based on an accumulation of sandstone blocks and river cobbles. More than 130 charcoal fragments were recovered inside. Junipers, accompanied by other shrubby taxa, were the most utilised firewood in this structure. Currently, the most common juniper species in the central Ebro basin are Corsican juniper (Juniperus phoenicea) and Spanish juniper (Juniperus thurifera), heliophilous and xerophilous shrubs suggesting that firewood collection was carried out in open landscapes. The presence of tree taxa in the dispersed charcoal could suggest the existence of other woody materials not documented in the archaeological record.

Figure 8. Espantalobos lithic density and position of hearths in level c (Geometric Mesolithic).

The oldest occupation at the Ésera and Isábena Rivers confluence is found at the Forcas-I rockshelter during the first moments of the Magdalenian presence at the Ebro Basin (Utrilla and Mazo, 2014). The last prehistoric habitat there is part of the Microlaminar Mesolithic horizon, dated between the first half of the $11^{\text {th }}$ millennium cal BP (level VII) and the late $12^{\text {th }}$ millennium (level IX). At the most recent level, a beautiful hearth was found over a large slab encircled by blocks. Charcoals were profuse (although they were not systematically recovered), and the general sediment colour was darkish (Figure 9, left). The neighbouring site of Forcas-II, barely $400 \mathrm{~m}$ upstream, was occupied in a recurrent way during the following millennia (perhaps due to the filling of the habitable space in Forcas-I?). The human presence starts with an industrially poor Denticulate Mesolithic (level $\mathrm{Ib}$ ) that, paradoxically, offers two ample hearths characterised by darkish and reddish sediments delimited by large, flat boulders (Figure 9, right) up to $40 \mathrm{~cm}$ long. As noted by the excavators, these large hearths are 
common in contemporary occupations such as Atxoste (Alday et al., 2003) levels V and VI (where sharp blocks were disposed of to pave parts of the dwelling area), Font del Ros (Roda et al., 2016) or Sota Palou (Carbonell y Mora, 1985). A similar fireplace found at Ángel 1 will be discussed later.

Figure 9. Left, accumulation of ashes, dark sediments and charcoals around a block-surrounded hearth from level VII at Forcas-I. Right, flat boulders, rubefacted sediments and ash accumulations from level Ib at Forcas-II (Utrilla and Mazo, 2014).

The Geometric Mesolithic appears at Forcas-II in two almost contemporary levels (Figure 10), II and IV, dated to the turn of the $9^{\text {th }}$ to the $8^{\text {th }}$ millennia cal BP. Despite the limited excavated surface (most of the site had been destroyed by modern human activities), those levels held interesting exempla of hearths. In level II structures based on flat slabs, boulders and conglomerate fragments (perhaps to isolate the floor from the immediate river water ponding?) were common. Some red deer selected parts (a jawbone, a scapula) appeared to have been deposited on purpose on top of these flat slabs. A similar situation can be seen in level IV barely a century later, although they are clearly separated by the sterile fluvial sediments of level III. There were many hollows and holes that penetrated level III underneath, and in some especially deep cases, even affect level II. One of the hollows was $50 \mathrm{~cm}$ in diameter and $33 \mathrm{~cm}$ deep and was filled with ashes. Next to it, a Cervus jawbone and an antler fragment were recovered. Level IV was in turn affected by holes excavated from the Early Neolithic level V. The lithic remains distribution showed a concentration of items in the central part of the excavated area, apparently unrelated to the position of the hearths. The wood charcoal analysis of the combustion structures excavated in levels II and IV has revealed that, again, the Scots pine (Pinus tp. sylvestris) is the most utilised firewood by the Mesolithic inhabitants of the site. Only in one of the level IV hearths were broadleaved species burnt.

Figure 10. Lithic elements distribution and structures scheme from Forcas II, levels II and IV. A wider line in the distributions signals the scheme areas (modified after Utrilla and Mazo, 2014).

The hut floor documented at Cabezo de la Cruz has already been described (Figure 4). Almost in its centre, a circular hole $(65 \times 59 \mathrm{~cm}$ wide, $20 \mathrm{~cm}$ deep) was found; it was full of ashy sediments, charcoal remains and some lithic elements. Nearby sediments appeared rubefacted due to the fire action. Some thin ash lenses around the hearth were thought to be the result of cleaning when those ashes were still warm, considering the rubefacted sediments found under them. The charcoal analysis (Badal, 2013) found Aleppo pine (Pinus halepensis) firewood, which was also utilised as raw material for the wooden structure. Seventy percent of the hearth assemblage and more than $90 \%$ of the dispersed charcoal are Aleppo pine. The hearth assemblage, where sclerophyllous shrubs (Juniperus sp., Evergreen Quercus) and other broadleaved trees (Deciduous Quercus, Populus/Salix) are documented, is surprisingly more diverse than the dispersed charcoals.

At Los Baños (Utrilla and Rodanés, 2004) no artificial structures were recognised, although the excavated area was limited: the adjacent road had destroyed most of the site, leaving only a narrow sediment strip that adhered to the rockshelter wall: the lithic remains distribution offered little information since the preserved sediment was a marginal area close to the rockshelter wall. The layer structure showed clearly that intense fires had taken place: the fertile levels were intensely grey, in deep contrast with 
the yellowish sterile deposits. At the bottom of the occupation (level 1b, Denticulate Mesolithic) a natural hollow in the rock floor appeared to have been used as a fireplace since it was full of ashes. Additionally, some scattered charcoals and cobbles were interpreted as the remains of dismantled hearths. As is typical in the Basin, pinewood dominated the assemblage. Both Aleppo pine (Pinus halepensis) and black pine (Pinus nigra) were recognised, while Juniperus, Quercus and Labietae (which includes a wide range of Mediterranean shrubs) appeared occasionally.

Plano del Pulido offers almost insurmountable problems to archaeologists because of its disturbed stratigraphic sequence (Utrilla and Bea, 2012): enormous fallen blocks from the rockshelter slid downhill (Figure 3c), dragging wide areas that currently are at the feet of the slope some metres away from their original position. Thus, it is impossible to attribute non-significant prehistoric remains (structure remains, fauna, common lithic elements) to a precise archaeological level.

The Matarraña Basin had been already studied in the mid-1950s, although systematic work with modern, accurate methodologies were first applied at Botiquería dels Moros in the early 1970s (Barandiarán, 1978), helping to establish this territory as a classic area for the study of the Mesolithic-Neolithic transition in the Iberian Peninsula. There, the first researchers had located many hollows filled with ashes, one of which was in a good state of preservation: bowl-shaped and small $(21 \times 21 \times 13 \mathrm{~cm})$, its supposed function was the conservation of embers. The same was proposed for some clay layers that were separated in different strata for the ashes inside a hearth. Barandiarán documented several simple fireplaces, most frequently in the northern part of the deposit: they were formed by selected homogeneous cobbles directly deposited on the natural floor, usually next to large rocks that had fallen from the roof (perhaps to protect the fires from winds). In the surrounding areas, where the sediment was rubefacted or mixed with ashes, there were many smudged limestone cobbles that could have come from previously dismantled hearths. In the fireplaces documented in level 4 (Geometric Mesolithic), there were between four to ten cobbles (Figure 6). In at least one case, the researchers thought that a large fallen block had been used as a structural element to arrange the dwelling area. Despite the wide surface excavated (up to $40 \mathrm{sq}$. $\mathrm{m}$ during the two main fieldwork periods), no functional areas could be identified.

At Costalena (Barandiarán and Cava, 1989), although the scattered archaeological remains could be found on a surface that surpassed 160 sq. m, the actual protection offered by the rockshelter barely covered 40 sq. m. No less than eleven fireplaces were found across the site's Mesolithic settlements, showing different features: some were simple ash lenses without any structural elements; others had been carefully surrounded by limestone blocks or even had a large slab as the hearth tile. Reddish heat-affected sediments were often found next to these fireplaces. The well-structured hearths were oval or circular-shaped, between 30 and $110 \mathrm{~cm}$ in diameter - the larger one was the only one found in the archaeological layer where it appeared- and usually were disposed of in shallow floor depressions (Figure 11). Burnt cobbles were not uncommon, perhaps due to their use as boiling stones.

Figure 11. Scheme of hearths from the middle and the bottom layers of level c3 at Costalena (modified after Barandiarán and Cava, 1989).

As previously said, no hearth was found inside the hut excavated at Secans, although evidence of burning (ashes deposits) was not unusual. The last analysed rockshelter 
from the Matarraña Basin is Pontet (Mazo and Montes, 1992; Montes, 1996): there, hearths featured similar characteristics to those documented at Costalena or Botiquería (Figure 12). The remains of at least three could be found on level e, Geometric Mesolithic; on the contrary, no combustion structure could be found in the Denticulate Mesolithic, even if the excavated area was small. Compared to other hearths from the most recent levels, those from level e are loosely delimited and simpler in structural terms: no cobbles or blocks were apparently employed to surround or pave them. They are mere hollow areas that are natural depressions of the underlying bedrock. The beststructured hearths are found at levels c inferior and c superior, which belong to the Neolithic period. The excavators noted that the hearths were carefully placed under the protection of the rock roof but formed an external fringe that could have isolated the inner space thanks to a heat curtain. The lithic element distribution in level e showed two main concentrations located under the palaeochannel shelter, but in the bestilluminated area, it was not close to the rockshelter wall. The highest concentration coincided with the best-conserved hearth.

Figure 12. Lithic elements distribution and location of hearths in Pontet level e.

We reported little data on the firewood used in Matarraña Basin due to the poor conservation of the biological remains and the absence of sampling strategies during the fieldworks. The modest Pontet anthracological record suggests that the firewood management would be carried out in an open landscape dominated by xerophyte conifers and evergreen oaks.

The two neighbouring sites located in the middle section of the Guadalope River, Ángel 1 and Ángel 2, include long and interesting prehistoric sequences. The closest to the riverbed, Ángel 1, was already occupied in the Gravettian, although the most recurrent human occupation occurred during the Early and Middle Holocene period. The first archaeological fieldwork (Sebastián, 1988) affected most of the Mesolithic occupation; since then, new work has been carried out (Utrilla et al., 2003; Utrilla et al., 2017). There, slabs pavements were localised at the bottom of some levels: at Ángel 1 at level 8d (Denticulate Mesolithic) on a surface of at least three sq. $\mathrm{m}$ and at Ángel 2, between levels 2a (Geometric Mesolithic) and 2b (Denticulate Mesolithic). In the first case, the extreme proximity to the river course could explain the desire to isolate the floor from a soggy terrain in high phreatic moments. However, the site of Ángel 2 is far enough from the river to propose that explanation, so perhaps, in this case, the prehistoric people were only looking for a flat and comfortable place on which to settle. The study of archaeological remains distribution was impossible in Ángel 1, where our team only excavated a minimum fraction of the original site, and little information was offered in Ángel 2, whose shape (a narrow strip of terrain less than two metres wide but almost ten metres long) was conditioned heavily by the human occupation. Sebastián found a hearth in the lower site, Ángel 1 (archaeological context 35) that was nicely arranged: the shallow hollow was encircled with lateral stones and a large slab at the bottom. A total of 21 charcoals were recovered inside: Scots pine (Pinus tp. sylvestris) is, as usual in the Basin, the only determined taxon. A scattered charcoal analysis reveals that, once again, pinewood is the most consumed firewood, accompanied only by junipers (Juniperus sp.) in level 8d (Denticulate Mesolithic).

\section{Discussion and conclusions}


The main part of the structures identified at Mesolithic sites from the Ebro Basin are fireplaces: sometimes, they are mere hollow areas filled with charcoals and ashes, but well-structured hearths, encircled with cobbles and even paved with slabs, are not uncommon. We suspect that some of the simpler hearths could be the remnants of more complex structures that were dismantled (on purpose by their own prehistoric groups or by natural actions) after their employment, although the possibility of unstructured hearths cannot be discarded. Nevertheless, the Ebro Basin sites are different from some Central European contexts (Sergant et al., 2006), where there were virtually no stones to circle the hearths. In our region, prehistoric groups could choose (and indeed they did) between fragments that had fallen from the paleochannels or cobbles from the neighbouring watercourses. The first model is followed strictly only in Peña-14, where despite the proximity to the river, the inhabitants preferred blocks from the rockshelter itself, while in the other sites the prehistoric occupants combined rock fragments and river cobbles. Unfortunately, we lack studies concerning the damage that the surrounding stones could have suffered from the fire: the archaeologists only mention that some appeared rubefacted, burnt or split. The same can be said for fire evidence in other archaeological remains: we find mentions of burnt cherts or bones, but for the moment, the data are anecdotal and not thorough.

The only exceptions to this relatively poor panorama can be found at Secans and Cabezo de la Cruz, where built dwelling structures could be documented. They were different: at Secans, a simple stone wall completed the protection already offered by the sandstone paleochannel, forming a rock habitation not different in shape from modernday traditional constructions used to gather livestock. Supposedly, a vegetal structure sealed the open space between the wall top and the rocky roof. As previously mentioned, the extremely poor preservation of the organic remains in that territory, which is responsible for the poor quality of the radiocarbon dates, prevents confirmation of this hypothetical vegetal roof. In the case of Cabezo de la Cruz, a flat terrain far from any rocky outcrop, archaeologists proposed that the dwellings were simple circular tents or huts formed by at least three wooden posts that should have been covered either with skins or with an accumulation of vegetal materials. The structure identified at Secans appears to suggest a more stable occupation than the easily movable tent deduced from the Cabezo de la Cruz postholes. Nevertheless, tents are considered (Fitch and Branch, 1960) easily transportable but fairly stable dwellings whose structure combines the highest structural stability with a maximum gain of habitable space. On the other hand, the investment of effort and time to build the simple stonewall found at Secans was not important, possibly a matter of some hours. It had the advantage of offering a small shelter that could last for short-term stays with minimum maintenance. We ignore the reason why this wall was erected at Secans and not elsewhere; additionally, the regrettable lack of organic remains at the Matarraña sites implies insurmountable difficulties in interpreting the real function of those prehistoric occupations. So far, the only functional analysis has studied their geometric microliths (Domingo, 2004), which were mostly employed as projectile points. Perhaps Secans had a unique role in the regional network of sites that needed a built structure. Concerning the stability of the occupation at Cabezo de la Cruz, its purposeful abandonment, given the scarce material remains, complicates the issue: as mentioned before, tents have been seen as more stable structures than huts, which are seen as highly peremptory dwellings built with gathered vegetal elements from the surroundings. In this sense, we can think that, aside from its relative material poorness, the human occupation at Cabezo de la Cruz lasted some time, perhaps in connection with the exploitation of the massive outcrops of goodquality Monegros chert located within a 15-minute walk range. 
During the Late Pleistocene and Holocene, we are sure that a flexible mixed habitation system was adopted by Mesolithic groups using rocky outcrops where available, openair emplacements and a combination of the two strategies, with campsites spreading out from the protection offered by paleochannels that could have acted as mere recognisable landmarks. There was a series of reasons for this behaviour: the favourable climatic conditions, the uncomfortable sloppy surfaces that many rockshelters can offer and the limitations imposed by a nomadic system restricted only to those rocky outcrops. Moreover, huge areas of the basin lack these geological features but should have been attractive for prehistoric groups: for example, the abovementioned Monegros chert outcrops are located in the central depression (García-Simón and Domingo, 2016), where the flat-top reliefs offer virtually no natural refuge. Significantly, no cave habitats are known in Mesolithic times in the Ebro Basin, in deep contrast to the frequent Upper Palaeolithic occupations and the even more frequent Early-Middle Neolithic employment of dozens of caves as livestock refuges and resting places. Some appealing examples are the caves of Abauntz (Utrilla et al., 2015) and Chaves (Baldellou, 2011), where intense Upper Magdalenian occupations are followed by a prolonged occupational gap until Neolithic times when the human presence was heavily resumed. This is possibly the only Mesolithic occupational preference we can firmly establish (Alday et al., 2017). The reason remains unknown, although sometimes it has been noted that between the Magdalenian and the Neolithic, some caves in the Ebro Basin (like Chaves, Utrilla, 1992) suffered floods and karstic reactivations that could have made them inhabitable.

The space arrangement in the sites would have adopted different complex solutions, even if most of the known sites have been traditionally interpreted as specialised shortterm occupations where prehistoric groups were not expected to accomplish a wide range of different tasks. When available, a full-scale functional analysis shows that the activities carried out during their use are more varied than traditionally suspected, covering a complete series of specialised and basic tasks: from game management to weapons maintenance or hide processing (Perales et al., 2016). Unfortunately, most of these sites have only been partially excavated or their preservation state is not ideal, hampering the identification of the distinct working areas. The extreme mobility that we suppose for those human groups implies easily transportable dwelling structures (tents) that leave a shallow archaeological imprint on the sites. Additionally, the poor conservation of organic remains in many of the studied areas adds more difficulties to the identification of what should have been mere wind-stoppers made with some posts, branches and perhaps some skins (Binford, 1998; Leesch and Bullinger, 2012). We must be aware that the finding of well-conserved dwelling or fire structures is extremely hazardous: many had already been dismantled by prehistoric groups when abandoning the space or were rapidly destroyed by animals or erosive processes, etc.

Is it possible to gather information regarding the intensity of Mesolithic human occupation from the number and size of the documented hearths? Although precise data are insufficient, we can envisage a certain relationship between the number of hearths per Mesolithic occupation and their size: the more copious they are in a campsite, the smaller they appear to be. These two situations (one large hearth vs. many smaller ones) could also be linked to different dwelling schemes: a single human visit vs. many shortterm reoccupations, but the lack of detailed micro-morphological studies of the structures do not allow us to see whether the fireplaces (the larger and smaller examples) were lit only once or many times from the remains of an ancient stone 
structure that could be easily refitted. We must be aware that most of these sites present a small lithic assemblage of thousands of lithic remains and at most several hundreds of retouched tools. From this data, it is difficult to determine intense human habitation for prolonged periods of time: they appear to be the result of recurrent short-term visits of small groups. Additionally, the easy availability of good-quality chert in most areas of the basin do not favour detectable cumulative strategies within the sites.

If we find the distribution of material remains, our data are far from being exhaustive and, when available, they are hardly informative. Most of the sites have been partially excavated or are poorly preserved: the currently available areas are a fraction of the ancient areas and, worst of all, we are not able to determine the representativeness of what has remained. Some of the sites, such as Espantalobos, Forcas-I or Peña-14, only present a narrow strip of terrain close to the rockshelter inner wall. Others, such as Esplugón, appear to offer better perspectives, but fieldwork is in an early stage, and only a minimal part of the site has been excavated. In many, namely, the Matarraña Basin sites, the problem is the absence of organic remains (charcoals, bones) probably due to edaphic processes related to episodes of extreme heat and aridity that pulverised the bones (Barandiarán and Cava, 2000). Concerning the tasks carried out in the sites, the only functional analyses applied so far have been focused on the huge collections of geometric microliths (Domingo, 2009). The main part of these collections that showed microwear or use damage had been employed as arrow points, supposedly in hunting activities that evidently occurred far from the dwelling place. The recovered projectile elements had been employed elsewhere and brought to the campsite, where they were eventually discarded and abandoned. However, for the moment, no functional analysis has involved "domestic" tools such as endscrapers, denticulates or blades. We cannot know whether some of the sites found close one to another (like in the Matarraña or Arba de Biel valleys) specialised in particular activities whose combination supported a whole human community or, on the contrary, every site was an independent habitat where a full scope of tasks occurred.

Figure 13. Theoretical scheme of the different firewood management strategies deduced from analysed hearths.

Concerning firewood management (Figure 13), charcoal fragments concentrated in hearths tend to be more homogeneous taxonomically than the scattered elements since they respond to the last fuel gathering. Badal (2013) explains that hollow hearths such as the one at Cabezo de la Cruz usually present more diversity than surface fireplaces: they have been used for a long time (different and possibly season-conditioned firewood gatherings), and they are harder to clean. Another possible explanation could be the disuse of the combustion structure prior to its abandonment (and hence some sort of covering with sand, earth or mud). This situation would have favoured its conservation and the taxonomic diversity documented inside, while outside the structure, the taxon that is better represented should be related to the constructive elements that would conform to the habitat structure. Regarding this, Figure 14 compares the recorded charcoal diversity in different hearth typologies documented in the Mesolithic sites. Concerning the woody plant resources gathered as fuel, raw material or building elements, opportunistic and locally biased strategies for the management of the most accessible resources appear to prevail in a poorly diversified environment.

Figure 14. Identified charcoal assemblages identified in hearths from the studied archaeological sites. 
This paper offers a synthetic review of the different space arrangement solutions documented in the Mesolithic occupations from the Middle Ebro Basin: nevertheless, many prehistoric dwelling places have not been located yet, and our knowledge is extremely biased to one type of location: rockshelters. Additionally, most of the sites are partially documented, either due to poor conservation of the stratigraphic sequence or incomplete archaeological work. The present situation, therefore, can only be considered provisional, since if we look at what we knew forty years ago and compare it to what we know now, there are profound motifs for future studies: as the network of excavated prehistoric sites grows and acquires density and complexity, our reconstruction of the past will be more accurate.

\section{Acknowledgements}

Archaeological fieldworks at the analyzed sites were possible thanks to public funding, either by the Ministry of Culture or by the regional Department or Culture. This particular study agrees with the objectives of the research projects HAR2014-59042-P, Transiciones climáticas y adaptaciones sociales en la Prehistoria de la Cuenca del Ebro, and HAR2015-65620-P, Paisaje y sociedad: el valle medio el Ebro entre el 6000 $y$ el 500 ANE. The authors belong to the research group H-07 Primeros pobladores del Valle del Ebro (Government of Aragón - European Social Fund) and to the University Institute of Environmental Sciences of the University of Zaragoza (IUCA). R. Domingo is a Ramón y Cajal researcher of the Ministry of Economy and Innovation (RyC201312613). M. Alcolea and M. Bea are researchers hired by the HAR2014-59042-P project.

\section{References}

Alcolea, M., Domingo, R., Piqué, R., Montes, L., 2016. Landscape and firewood at Espantalobos Mesolithic site (Huesca, Spain). First results. Quat. Int. doi:10.1016/j.quaint.2016.10.007

Alday, A., 2006. El Mesolítico de muescas-denticulados en la Cuenca del Ebro y el Litoral Mediterráneo peninsular. Memorias de Yacimientos Alaveses.

Alday, A., Domingo, R., Sebastián, M., Soto, A., Aranbarri, J., Gonzáñez-Sampériz, P., Sampietro-Vattuone, M.M., Utrilla, P., Montes, L., Peña-Monné, J.L., 2017. The silence of the layers: Archaeological site visibility in the Pleistocene-Holocene transition at the Ebro Basin. Quat. Sci. Rev. in press.

Alday, A., Fernández Eraso, J., Yusta, I., 2003. Suelos de habitación-suelos de corrales: los casos de Atxoste y Los Husos. Veleia 20, 183-225.

Badal, E., 2013. Los usos de los vegetales leñosos en el Cabezo de la Cruz (La Muela, Zaragoza) durante la ocupación mesolítica, en: Rodanés, J.M., Picazo, J.V. (Eds.), El campamento mesolítico del Cabezo de la Cruz. La Muela, Zaragoza. Zaragoza, pp. 83-99.

Baldellou, V., 2011. La cueva de Chaves (Bastarás-Casbas, Huesca), en: Las primeras producciones cerámicas. El VI milenio cal aC en la península ibérica. Saguntum Extra-11, Valencia, pp. 141-144.

Barandiarán, I., 1978. El abrigo de la Botiquería dels Moros. Mazaleón (Teruel). Excavaciones arqueológicas de 1974. Cuad. Prehist. y Arqueol. Castellon. 49-142.

Barandiarán, I., Cava, A., 2000. A propósito de unas fechas del Bajo Aragón: reflexiones sobre el Mesolítico y el Neolítico en la Cuenca del Ebro. SPAL 9, 293 326.

Barandiarán, I., Cava, A., 1989. La ocupación prehistórica del Abrigo de Costalena 
(Maella, Zaragoza), Arqueología Aragonesa. Diputación General de Aragón, Zaragoza.

Binford, L.R., 1998. Hearth and home: the spatial analysis of ethnographically documented rock shelter occupations as a template for distinguishing between human and hominid use of sheltered space, en: XIII UISPP Congress Proceedings, Forli 8-14 September 1996. pp. 229-239.

Carbonell, E., Mora, R., 1985. Anàlisi espacial d'un campament prehistoric del PostGlacial. Sota Palou (Campdevànol). Cypsela V, 35-45.

Domingo, R., 2009. Caracterización funcional de los microlitos geométricos: el caso del Valle del Ebro, en: Utrilla, P., Montes, L. (Eds.), El Mesolítico Geométrico en la Península Ibérica. Universidad de Zaragoza, Zaragoza, pp. 375-390.

Domingo, R., 2004. La funcionalidad de los microlitos geométricos en yacimientos del Bajo Aragón: los casos de Botiquería dels Moros y Secans (Mazaleón, Teruel) y Costalena (Maella, Zaragoza). Salduie 4, 41-84.

Domingo, R., Martínez-Bea, M., Utrilla, P., 2010. Una nueva ocupación neolítica en el río Guadalope: la campaña de 2009 en el abrigo de Ángel 2. Saldvie1 10, 225-235.

Fernández Ruiz, J., 2016. Las estructuras de combustión en la prehistoria reciente en el nordeste de la península ibérica. Universitat Autònoma de Barcelona.

Fitch, J.M., Branch, D.P., 1960. Primitive Architecture and Climate. Sci Am 23 (6), 134-144. doi:10.1038/scientificamerican1260-134

Fortea, J., 1973. Los complejos microlaminares y geométricos del epipaleolítico mediterraneo español. Memorias del Semin. Prehist. y Arqueol., Memorias del Seminario de Prehistoria y Arqueología; Universidad de Salamanca.

Garcia-Castellanos, D., Vergés, J., Gaspar-Escribano, J., Cloetingh, S., 2003. Interplay between tectonics, climate, and fluvial transport during the Cenozoic evolution of the Ebro Basin (NE Iberia). J. Geophys. Res. J. Geophys. Res 108. doi:10.1029/2002JB002073

García-Diez, M., Vaquero, M., 2015. Looking at the Camp: Paleolithic Depiction of a Hunter-Gatherer Campsite. PLoS One 10. doi:10.1371/journal.pone.0143002

García-Simón, L.M., Domingo, R., 2016. The Monegros-type chert: Petrographic characterisation and prehistoric use. J. Lithic Stud. 3.

González-Sampériz, P., 2004. Evolución paleoambiental del sector central de la cuenca del Ebro durante el Pleistoceno Superior y Holoceno. Instituto Pirenaico de Ecología-CSIC, Zaragoza.

Leesch, D., Bullinger, J., 2012. Identifying dwellings in Upper Palaeolithic open-air sites - The Magdalenian site at Monruz and its contribution to analysing palimpsests. A mind set flint. Stud. honour Dick Stapert 165-181.

Mazo, C., Montes, L., 1992. La transición Epipaleolítico - Neolítico antiguo en el abrigo de El Pontet (Maella, Zaragoza), en: Utrilla, P. (Ed.), Aragón I Litoral mediterráneo: intercambios culturales durante la Prehistoria. pp. 243-254.

Mazo, C., Montes, L., 1992. La transición Epipaleolítico-Neolítico antiguo en el abrigo de «El Pontet» ( Maella, Zaragoza), en: Aragón Litoral Mediterráneo : intercambios culturales durante la prehistoria : en homenaje a Juan Maluquer de Motes. pp. 243-254.

Montes, L., 1996. El IV milenio en el Bajo Aragón, en: Rubricatum: revista del Museu de Gavà. El Museu, pp. 757-767.

Montes, L., Domingo, R., Cuchi, J.A., Alcolea, M., Sola, C., 2015. Completando el mapa de la Cuenca del Ebro: el Mesolítico del IX milenio cal BP de Espantalobos (Huesca, España). Munibe Antropol. 66, 119-133. doi:10.21630/maa.2015.66.06

Montes, L., Domingo, R., González-Sampériz, P., Sebastián, M., Aranbarri, J., Castaños, 
P., García-Simón, L.M., Alcolea, M., Laborda, R., 2016b. Landscape, resources and people during the Mesolithic and Neolithic times in NE Iberia: The Arba de Biel Basin. Quat. Int. 403, 133-150. doi:10.1016/j.quaint.2015.05.041

Mora, R., Benito-Calvo, A., Martínez-Moreno, J., Marcen, P.G., de la Torre, I., 2011. Chrono-stratigraphy of the Upper Pleistocene and Holocene archaeological sequence in Cova Gran (south-eastern Pre-Pyrenees, Iberian Peninsula). J. Quat. Sci. 26, 635-644. doi:10.1002/jqs. 1486

Olive, M., Taborin, Y., 1989. Nature et fonction des foyers préhistoriques : actes du Colloque international de Nemours, 12-13-14 mai 1987. Association pour la promotion de la recherche archéologique en Ile-de-France.

Peña-Monné, J.L., Pellicer, F., Julián, A., Chueca, J., Echeverría, M.T., Lozano, M.V., Sánchez Fabre, M., 2002. Mapa geomorfológico de Aragón. Consejo de Protección de la Naturaleza de Aragón.

Peña-Monné, J.L., Sancho-Marcén, C., Rubio-Fernández, V., Longares-Aladrén, L.A., 2005. Aportaciones desde la geomorfología y la geoarqueología al conocimiento de los paleoambientes holocenos del NE de España., en: X Coloquio Ibérico de Geografía. pp. 1-15.

Perales, U., Soto, A., Alday, A., 2016. El análisis tecno-funcional y la gestión de la industria lítica del nivel IIIb2 de Atxoste (Álava, Epaña). Munibe Antropol. 67, 313-323. doi:10.21630/maa.2016.67.mis12

Roda Gilabert, X., Martínez-Moreno, J., Torcal, R.M., 2016. Ground stone tools and spatial organization at the Mesolithic site of font del Ros (southeastern PrePyrenees, Spain). J. Archaeol. Sci. Reports 5, 209-224. doi:10.1016/j.jasrep.2015.11.023

Rodanés, J.., Picazo, J., 2009. La cabaña mesolítica de Cabezo de la Cruz (La Muela, Zaragoza), en: Utrilla, P., Montes, L. (Eds.), El Mesolítico Geométrico en la Península Ibérica. Zaragoza, pp. 327-341.

Rodanés, J.M., Picazo, J. V., 2013. El campamento mesolítico del Cabezo de la Cruz. La Muela, Zaragoza. Monografías Arqueológicas. Prehistoria 45. Universidad de Zaragoza, Zaragoza.

Rodanés, J.M., Tilo, M.A., Fernández, N.R., 1996. El abrigo de Els Secans (Mazaleón, Teruel). Al-Qannis 6, 2-107.

Rodanés Vicente, J.M., Picazo Millán, J.V., 2008. La cabaña Mesolítica del Cabezo de la Cruz (La Muela, Zaragoza), en: El Mesolítico geométrico en la Península ibérica. Prensas de la Universidad, pp. 327-341.

Sebastián, A., 1988. Nuevos datos sobre la cuenca media del río Guadalope. El abrigo del Barranco Hondo y el abrigo Ángel. Teruel Rev. del Inst. Estud. Turolenses, ISSN 0210-3524, Vol. 79, No 2, 1988, págs. 75-92 79, 75-92.

Sergant, J., Crombé, P., Perdaen, Y., 2006. The «invisible» hearths: A contribution to the discernment of Mesolithic non-structured surface hearths. J. Archaeol. Sci. 33, 999-1007. doi:10.1016/j.jas.2005.11.011

Soto, A., Alday, A., Montes, L., Utrilla, P., Perales, U., Domingo, R., 2015. Epipalaeolithic assemblages in the Western Ebro Basin (Spain): The difficult identification of cultural entities. Quat. Int. 364, 144-152. doi:10.1016/j.quaint.2014.05.041

Utrilla, P., 1992. Aragón/Litoral Mediterráneo. Relaciones durante el Paleolítico, en: Utrilla, P. (Ed.), Aragón/Litoral mediterráneo: intercambios culturales durante la Prehistoria. Diputación Provincial de Zaragoza, pp. 9-35.

Utrilla, P., Berdejo, A., Obón, A., Laborda, R., Domingo, R., Alcolea, M., 2016. El abrigo de El Esplugón (Billobas-Sabiñánigo, Huesca). Un ejemplo de transición 
Mesolítico-Neolítico en el Prepirineo central, en: Del neolític a l'edat del bronze en el Mediterrani occidental. Estudis en Homenatge a Bernat Martí Oliver. Trabajos varios del SIP, Museo de Valencia, Valencia, pp. 75-96.

Utrilla, P., Domingo, R., Bea, M., 2017. El Arenal de Fonseca. Ocupaciones prehistóricas del Gravetiense al Neolítico. Monografías Arqueológicas. Prehistoria 52. Universidad de Zaragoza, Zaragoza.

Utrilla, P., Domingo, R., Martínez Bea, M., 2003. La campaña del año 2002 en el Arenal de Fonseca (Ladruñán, Teruel ). Saldvie 3, 301-311.

Utrilla, P., Mazo, C., 2014. La Peña de Las Forcas (Graus, Huesca). Un asentamiento estratégico en la confluencia del Ésera y el Isábena. Monografías Arqueológicas, 46. Universidad de Zaragoza.

Utrilla, P., Mazo, C., Domingo, R., 2015. Fifty thousand years of prehistory at the cave of Abauntz (Arraitz, Navarre): A nexus point between the Ebro Valley, Aquitaine and the Cantabrian Corridor. Quat. Int. 364, 294-305. doi:10.1016/j.quaint.2014.06.022

Utrilla, P., Mazo, C., Domingo, R., 2014. Los abrigos de Forcas en la dinámica cultural del Valle del Ebro, en: Utrilla, P., Mazo, C. (Eds.), La Peña de Las Forcas (Graus, Huesca). Un asentamiento estratégico en la confluencia del Ésera y el Isábena. Monografías Arqueológicas. Prehistoria, 46. Universidad de Zaragoza, pp. 345-405.

Utrilla, P., Montes, L., 2009. El Mesolítico geométrico en la Península ibérica, Monografías arqueológicas. Prehistoria 44. Monografías Arqueológicas. Prehistoria 44. Universidad de Zaragoza, Zaragoza.

Utrilla, P., Montes, L., 2007. La période 19000-14000 BP dans le bassin de l'Èbre. Bull. la Société préhistorique française 104, 797-807.

Utrilla, P., Montes, L., Mazo, C., Martínez Bea, M., Domingo, R.., Martínez-Bea, M., Martínez Bea, M., Domingo Martínez, R., 2009. El mesolítico geométrico en Aragón, en: Utrilla, P., Montes, L. (Eds.), El mesolítico geométrico en la Península Ibérica, 2009, ISBN 978-84-92522-07-1, págs. 131-190. Universidad de Zaragoza, pp. 131-190.

Utrilla, P., Rodanés, J.M., 2004. Un asentamiento epipaleolítico en la cuenca del río Martín. El abrigo de Los Baños (Ariño, Teruel). Monografías Arqueológicas 39. Universidad de Zaragoza. Zaragoza.

Utrilla, P., Rodanés, J.M., 2004. Un asentamiento epipaleolítico en el valle del río Martín: el abrigo de Los Baños (Ariño, Teruel). Monografías Arqueológicas 39. Universidad de Zaragoza, Zaragoza.

Utrilla, P., Bea, M., 2012. El asentamiento neolítico del Plano del Pulido (Caspe, Zaragoza). Rubricatum Rev. del Mus. Gavà 5, 69-78. 


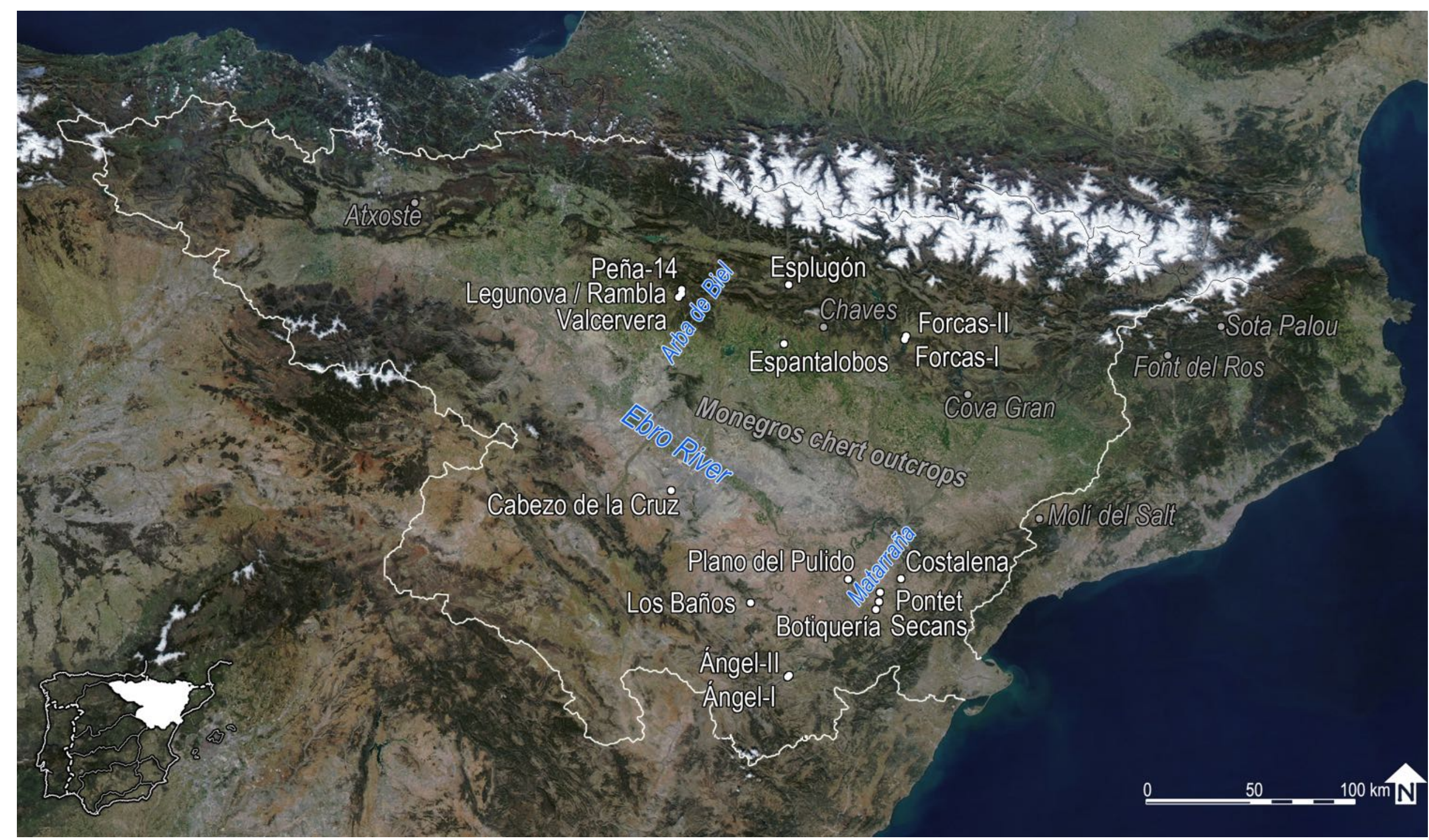



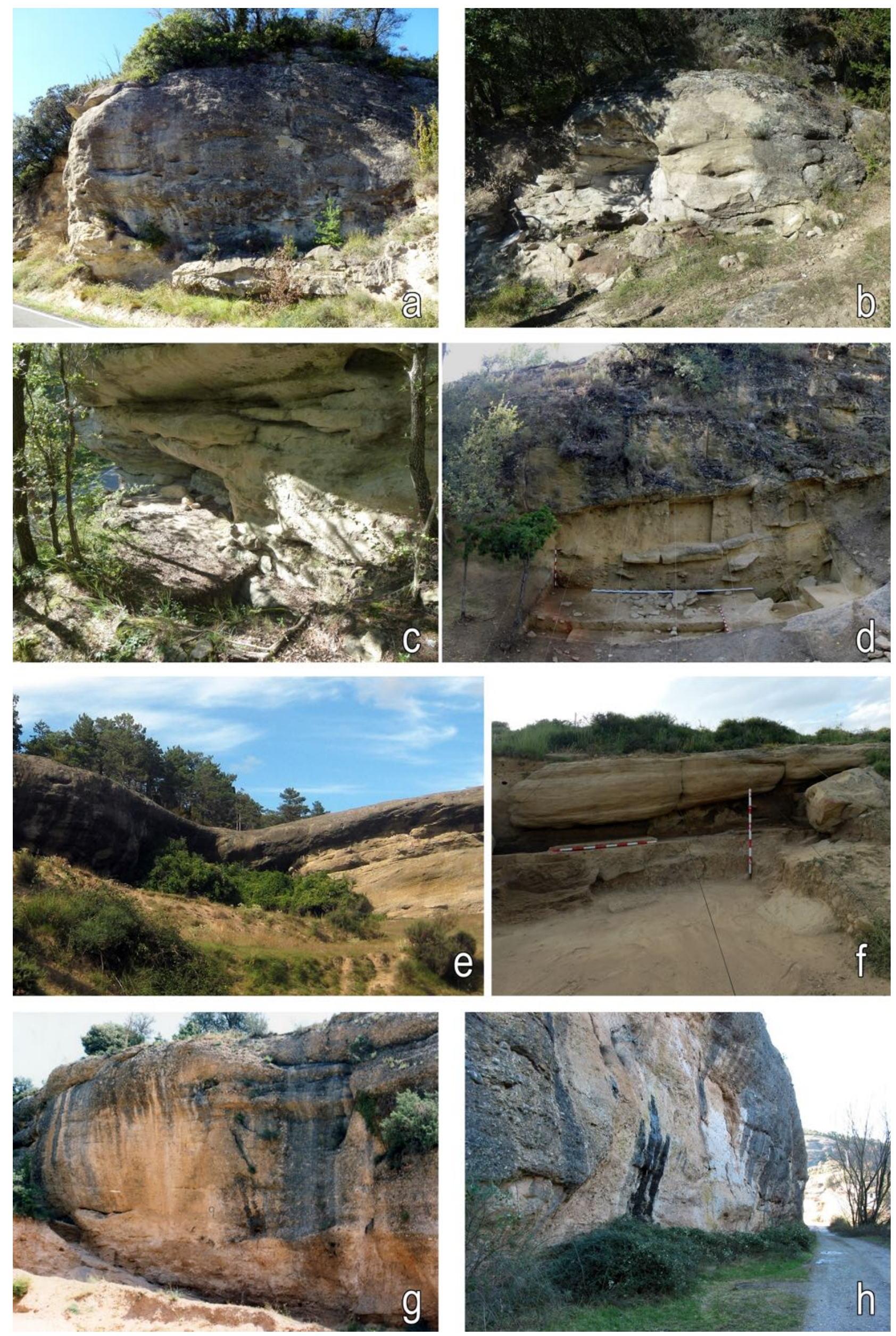



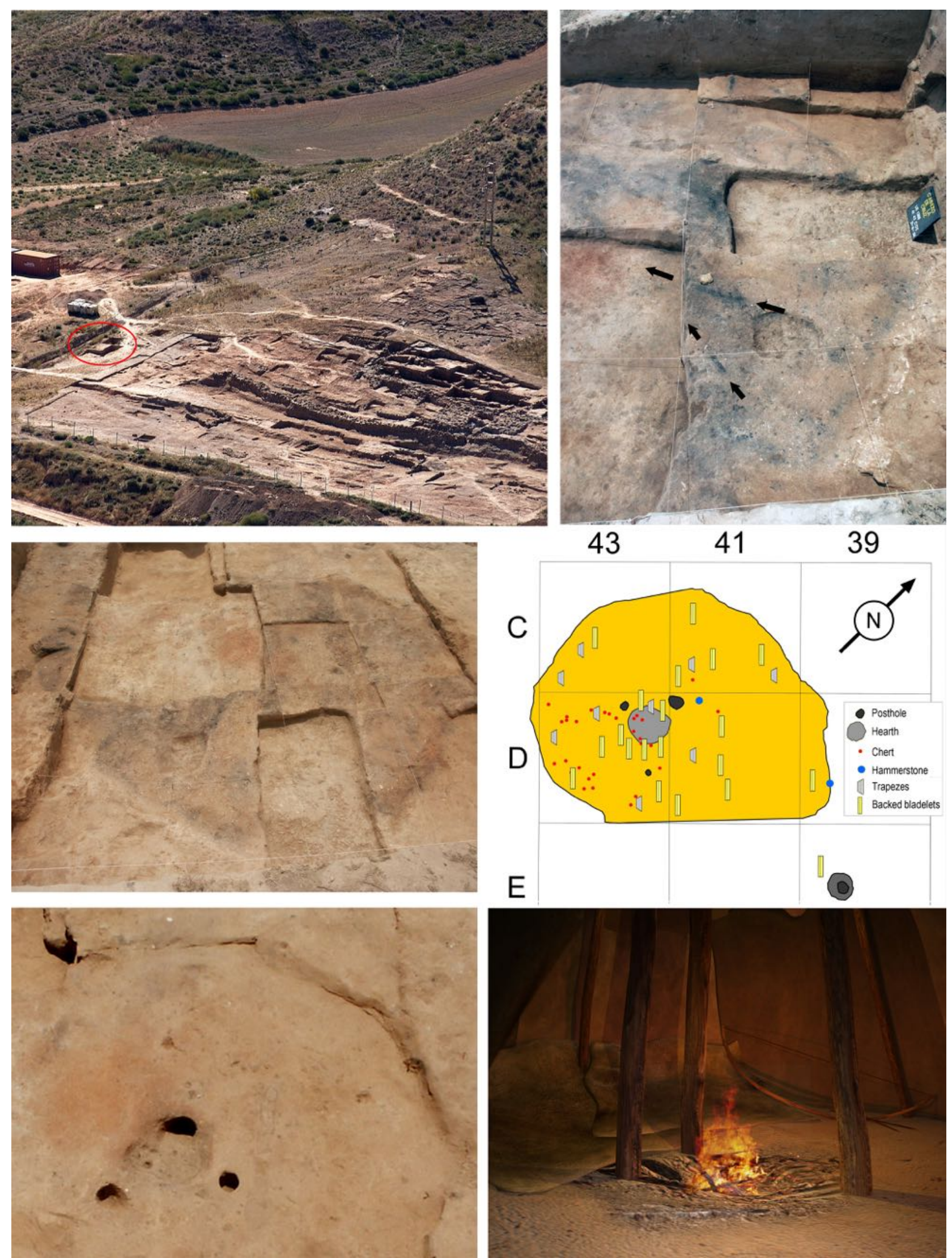

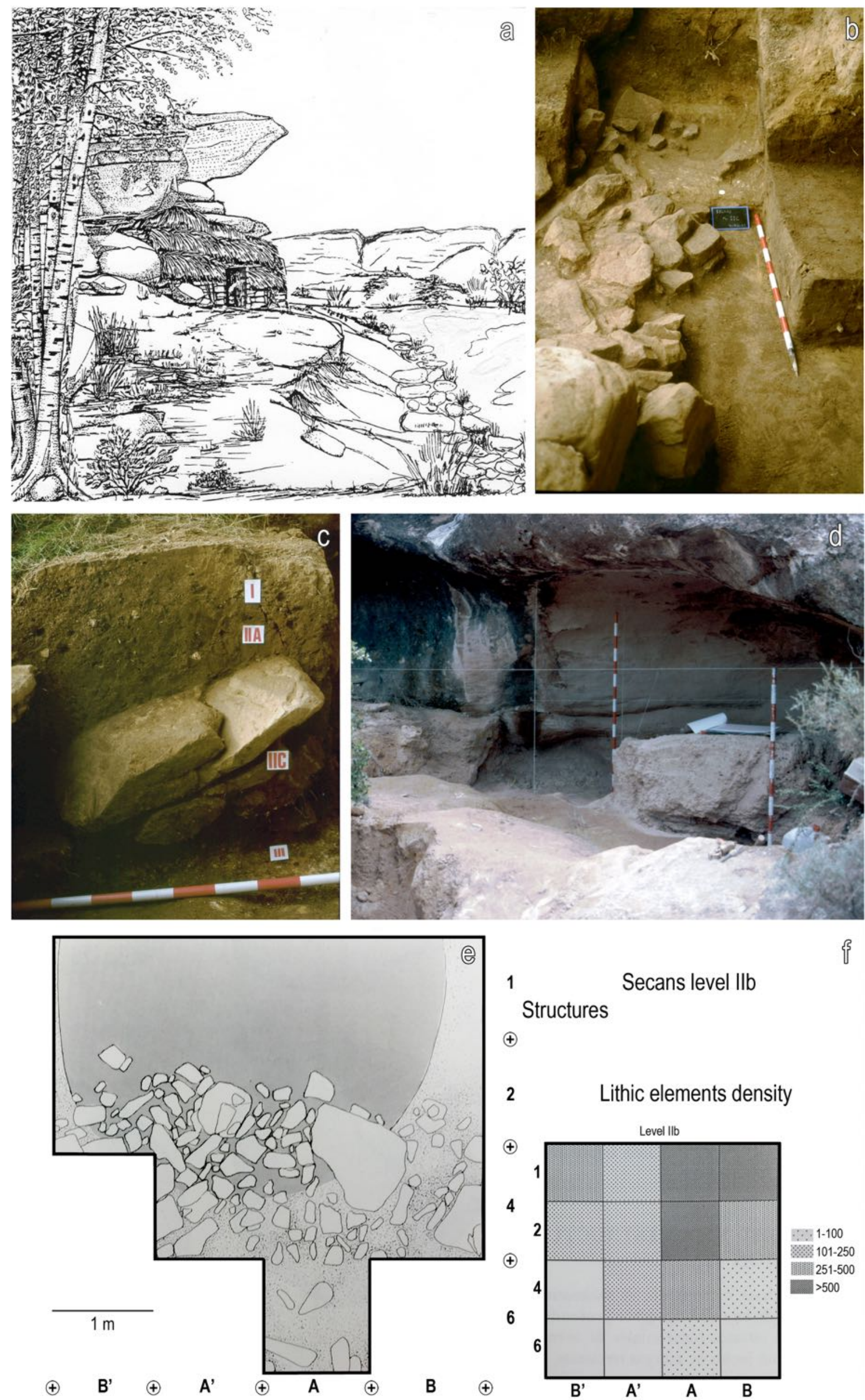

Secans level llb Structures

†

$2 \quad$ Lithic elements density

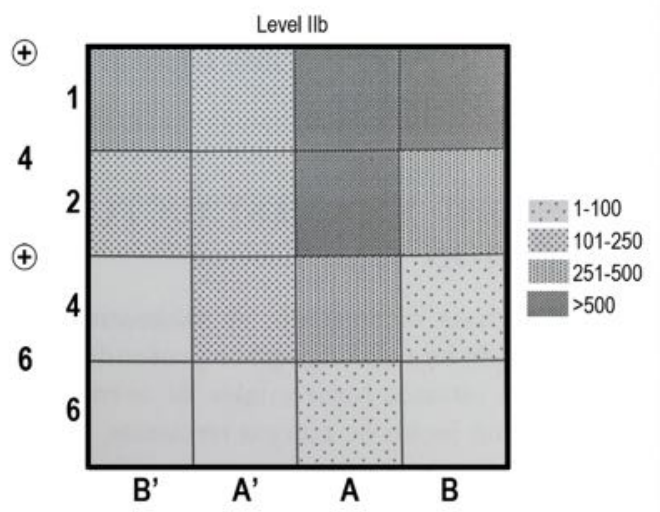




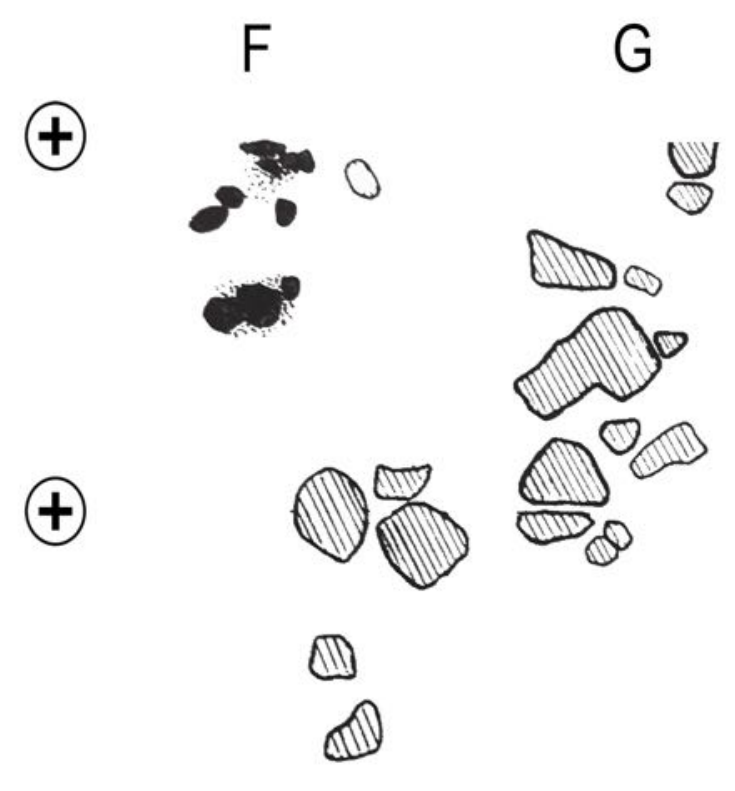

H

$\oplus$

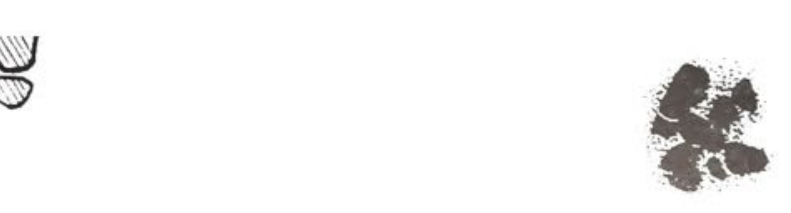

1

$\oplus$

$\oplus$

$\oplus$

$\oplus$

$\oplus$

$\oplus$

$\tilde{N}$

0

P

Q





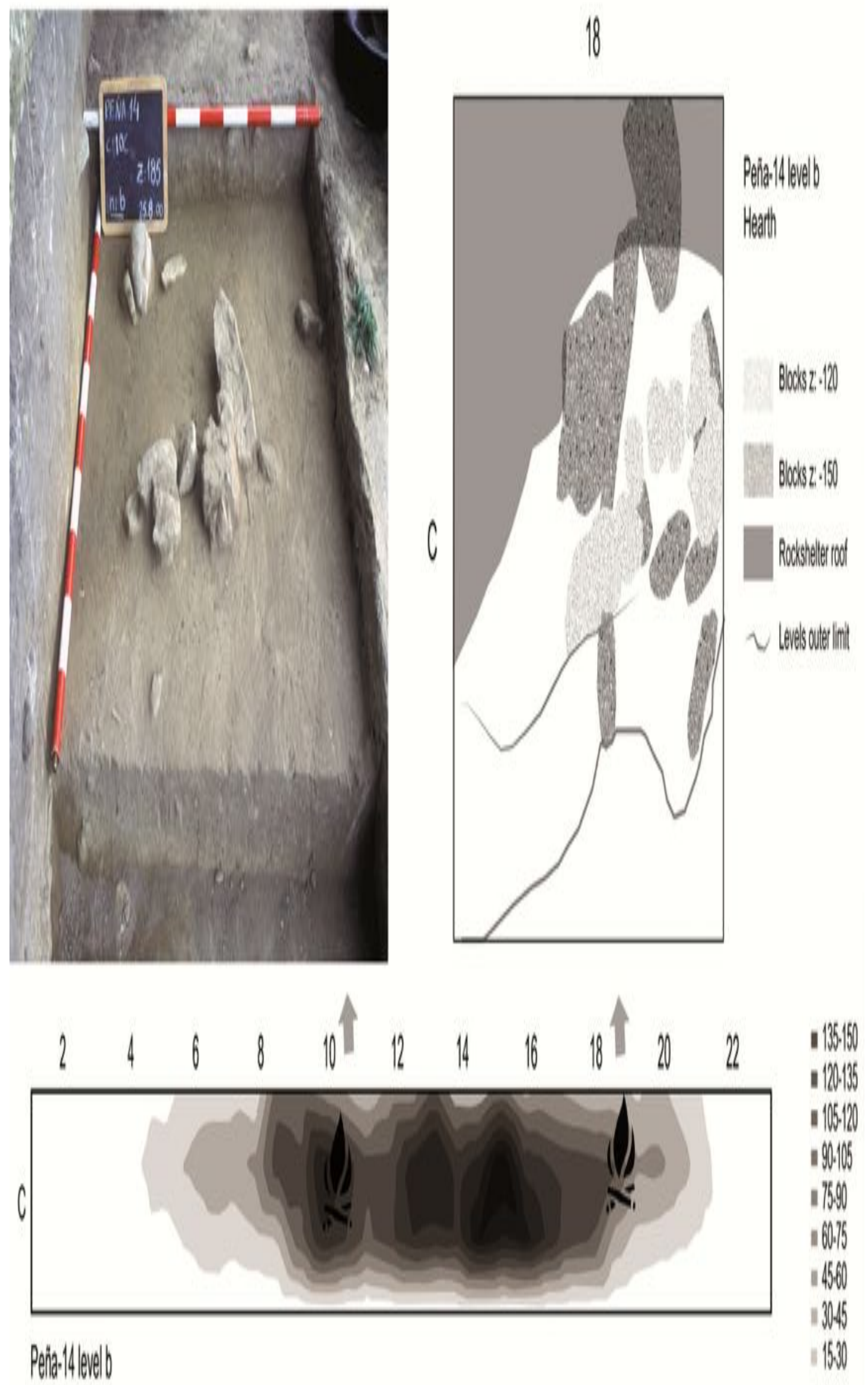
Espantalobos, level c. Chert distribution



Espantalobos, level c. Non-siliceous lithics distribution

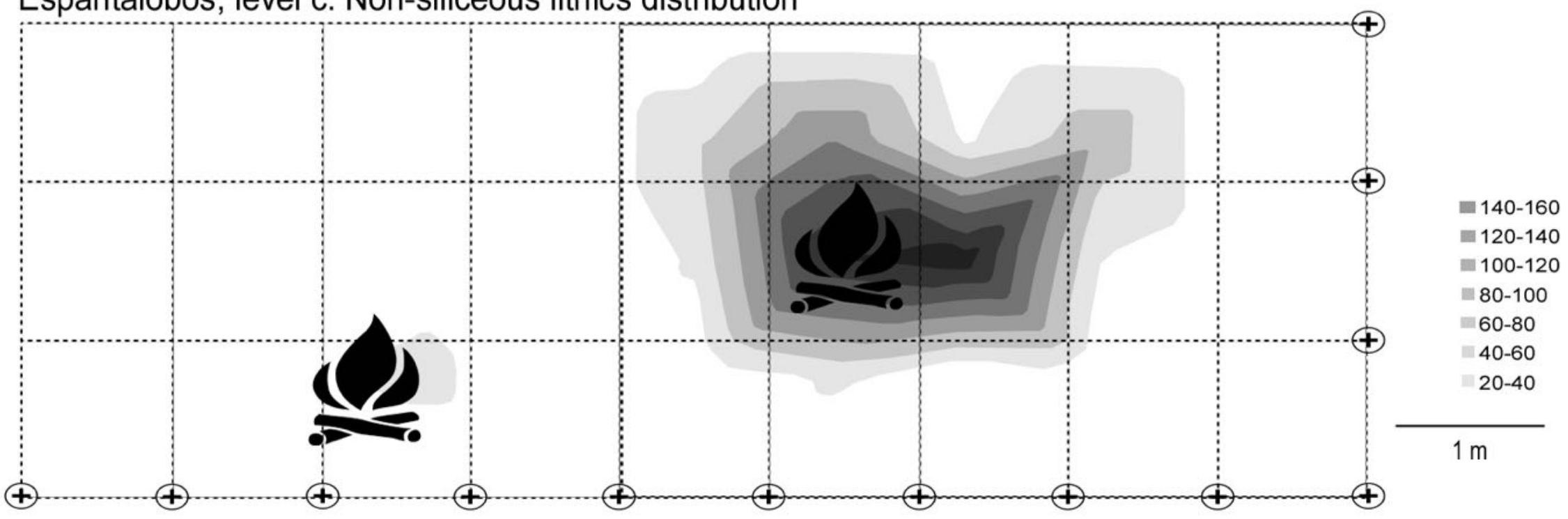



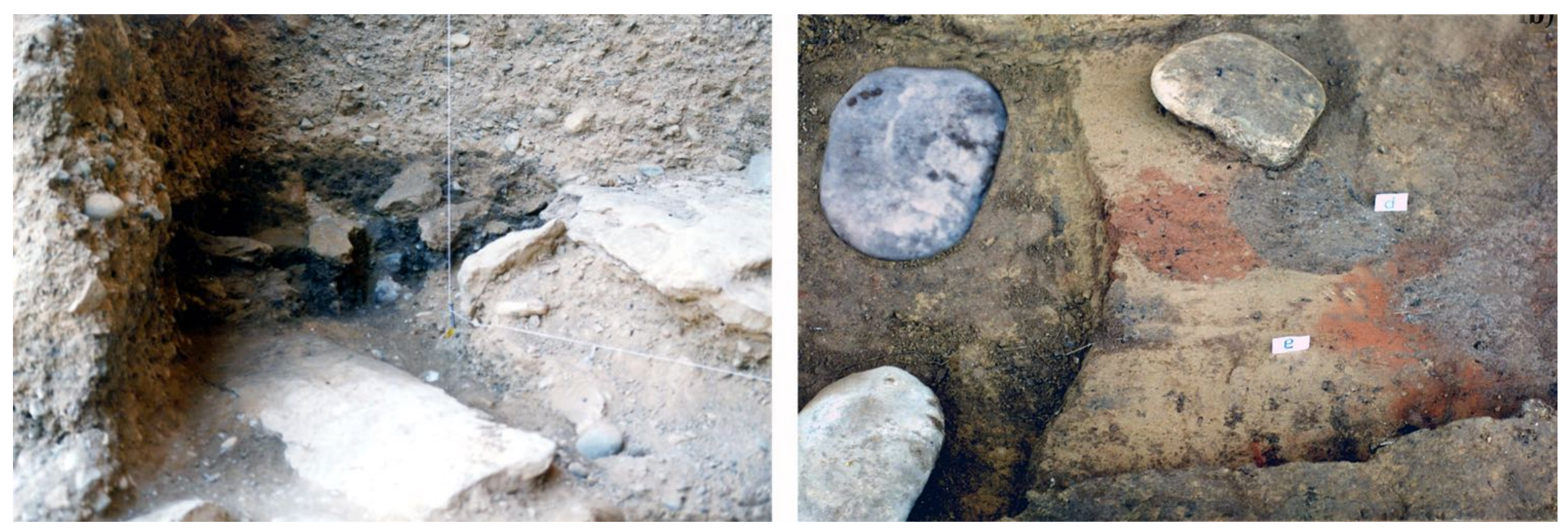

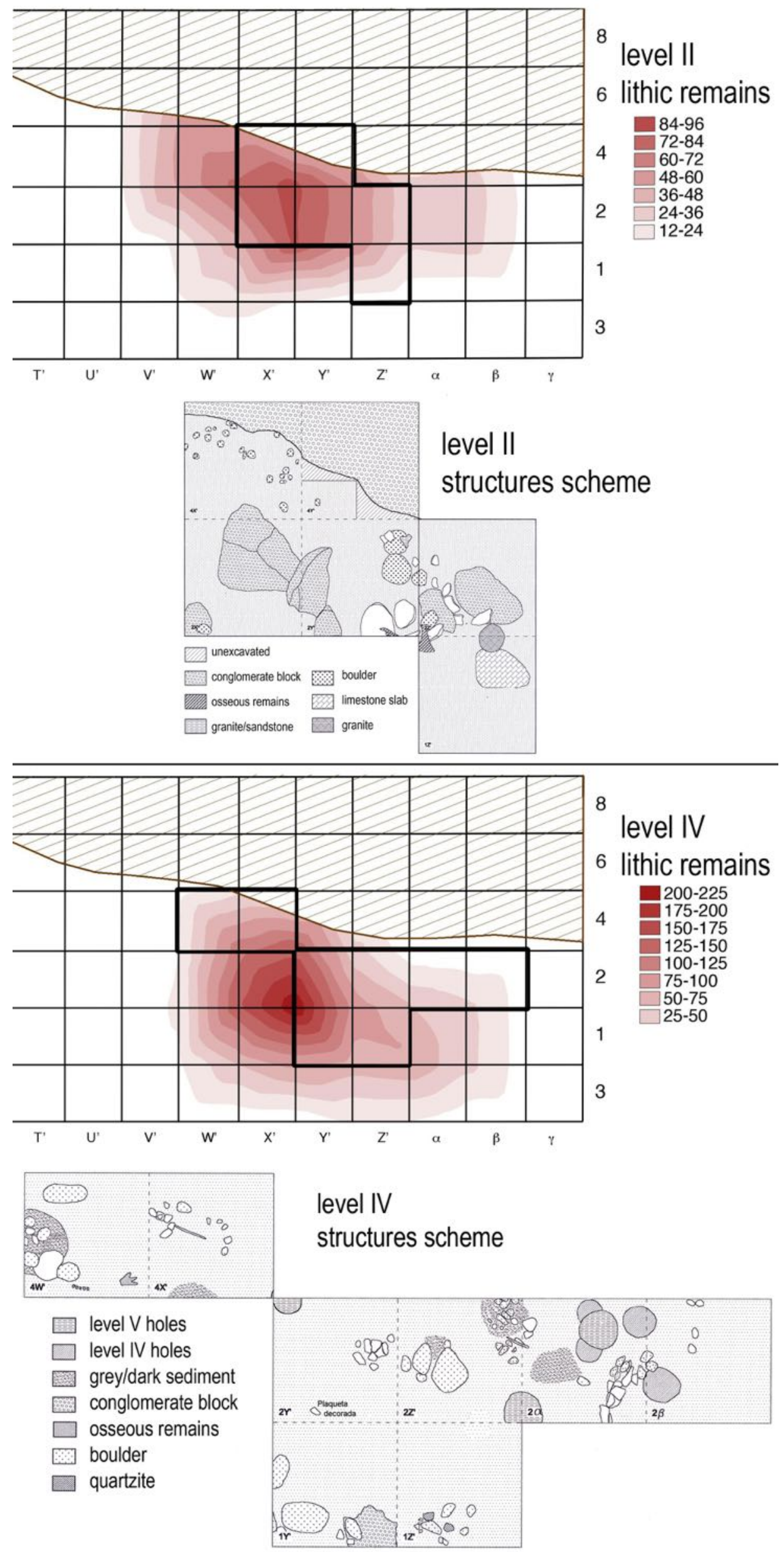


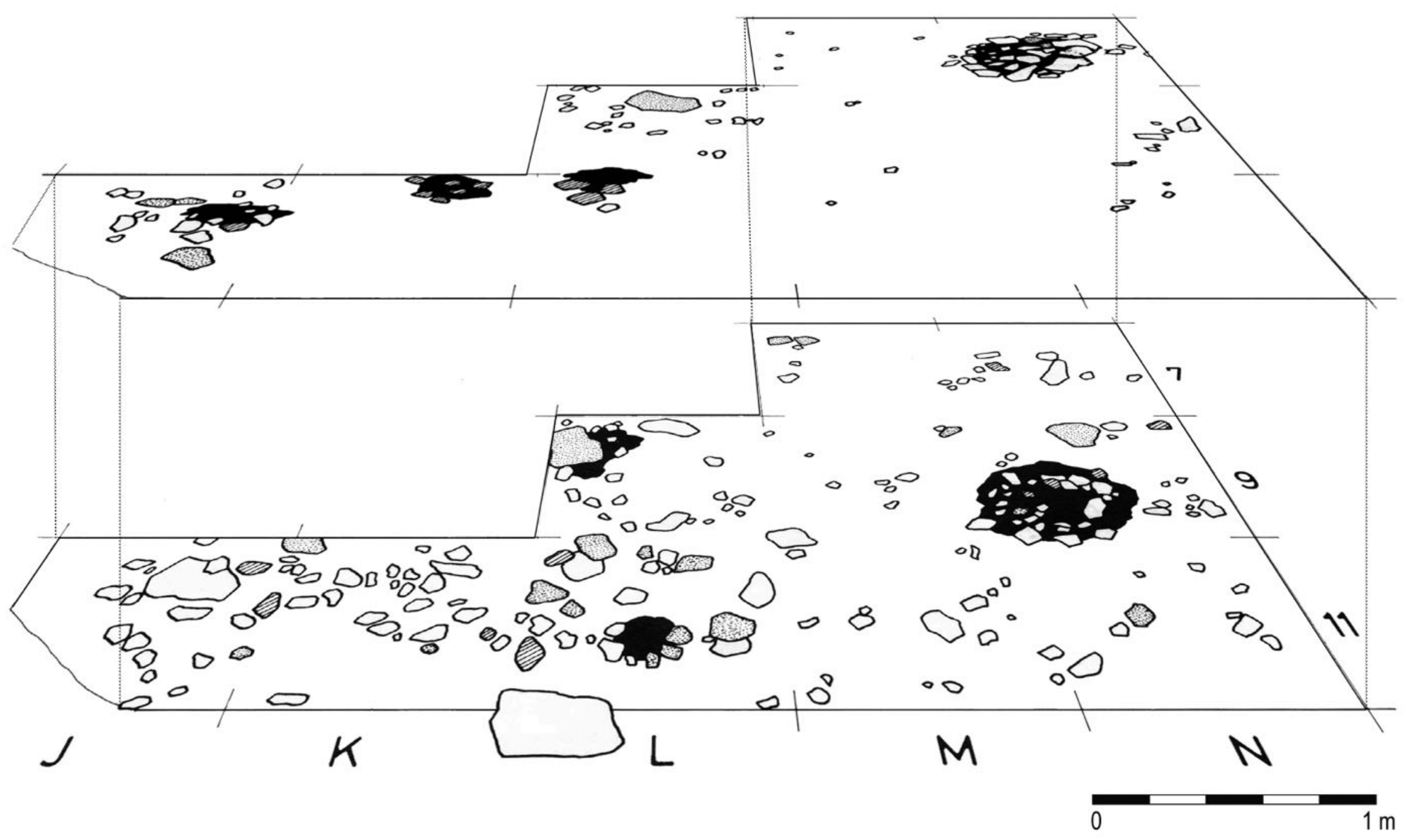




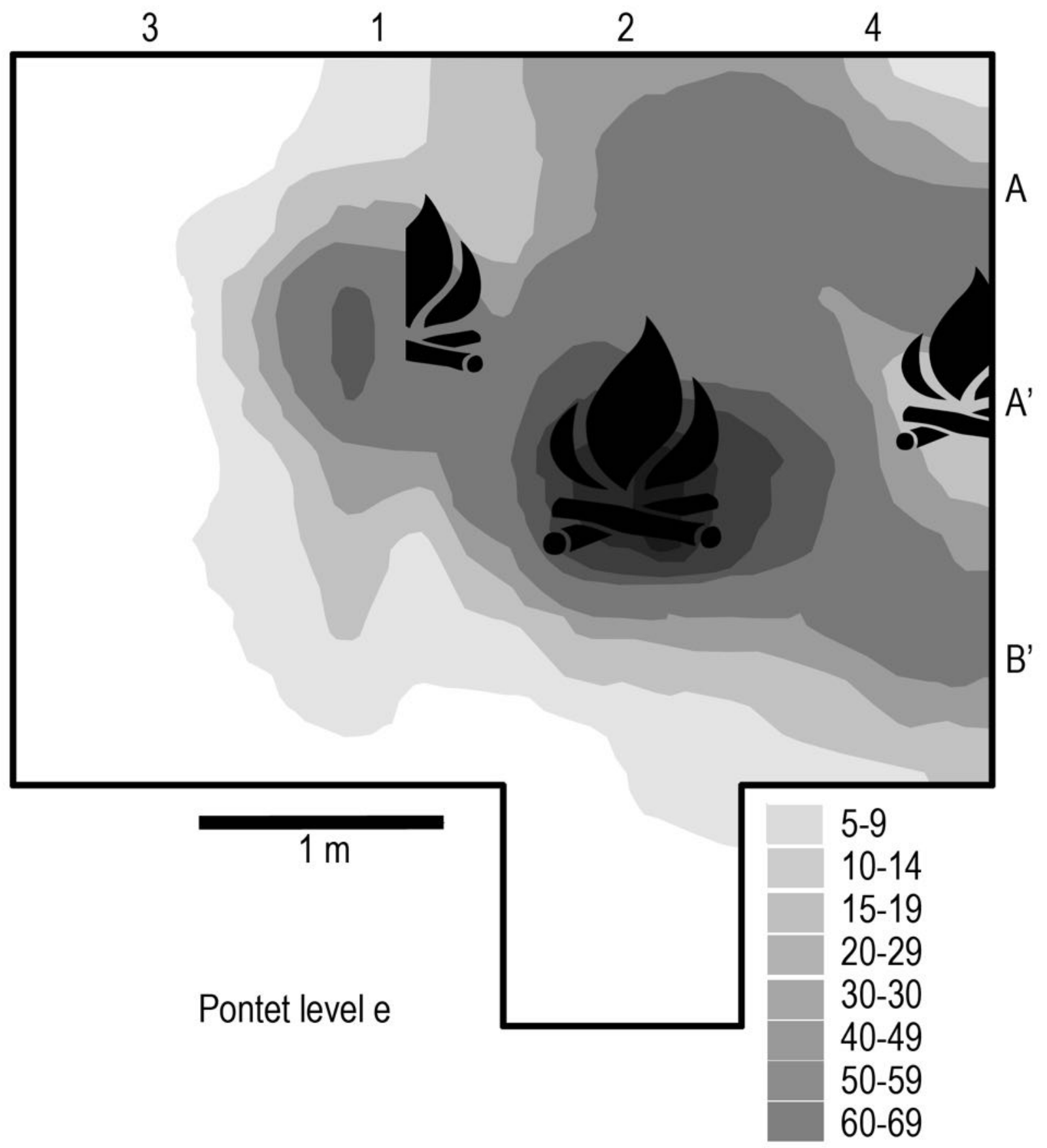




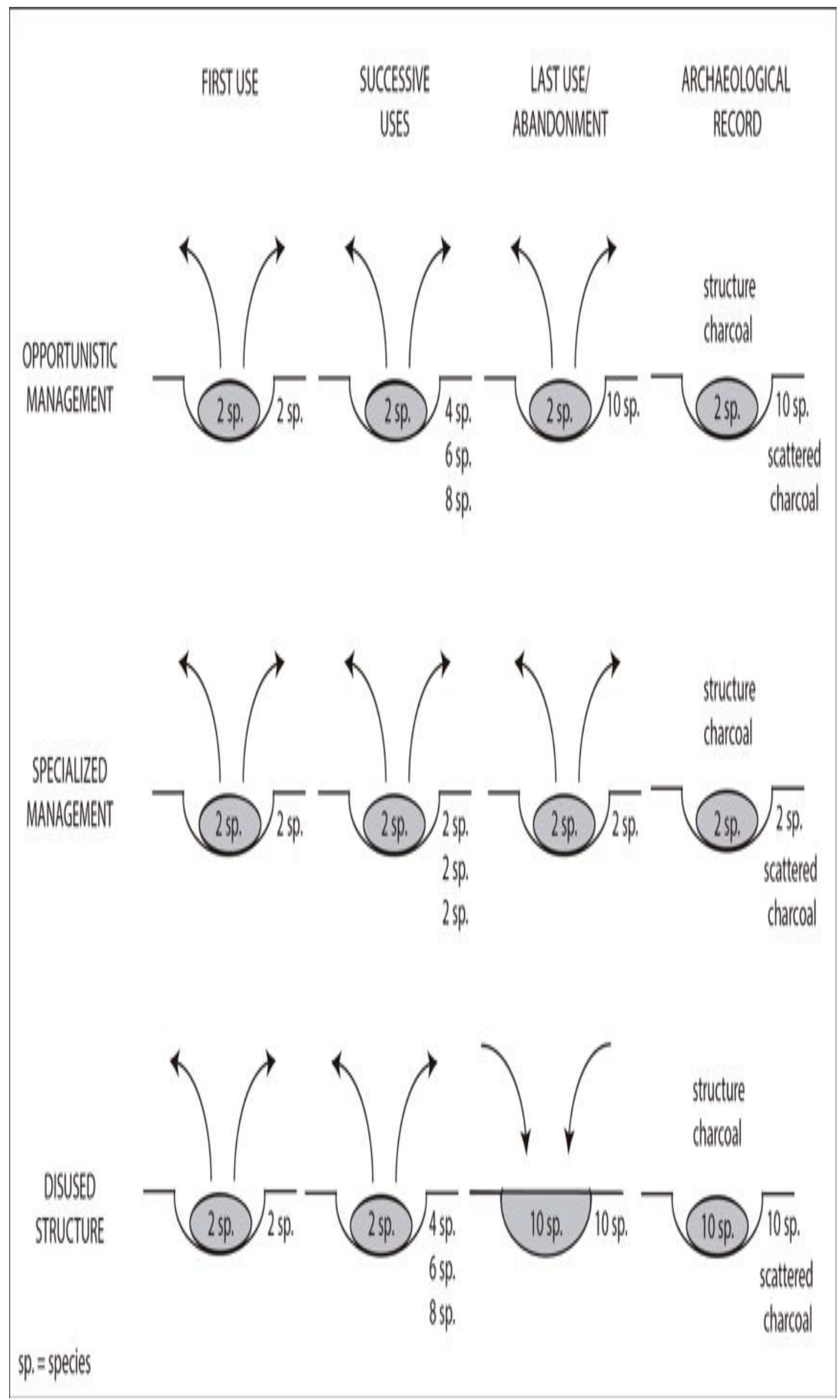




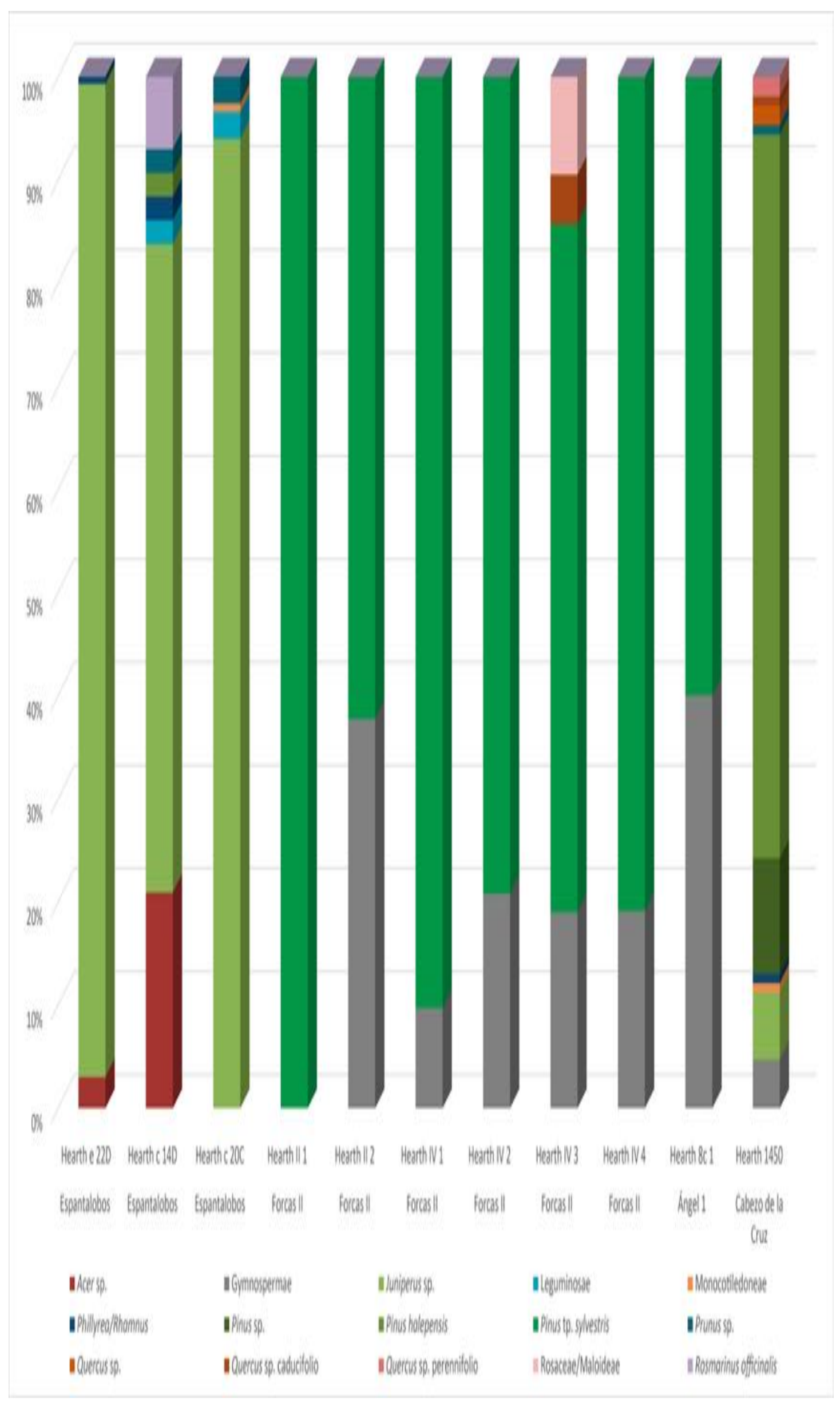




\begin{tabular}{|c|c|c|c|c|c|c|c|}
\hline $\begin{array}{c}\text { Perio } \\
\text { d }\end{array}$ & Site & Lab. reference & Date & \pm & \multicolumn{2}{|c|}{ calBP } & Reference \\
\hline GM & Valcervera & GrA-27876 & 6815 & 45 & 7580 & 7727 & (Montes et al., 2015) \\
\hline GM & Forcas II & Grn-22688 & 6900 & 45 & 7656 & 7843 & (Utrilla and Mazo, 2014) \\
\hline GM & Forcas II & Beta-60773 & 6940 & 90 & 7618 & 7941 & (Utrilla and Mazo, 2014) \\
\hline GM & Esplugón & Beta-306723 & 6950 & 50 & 7680 & 7925 & (Utrilla et al., 2016) \\
\hline GM & Ángel 2 & Beta-266112 & 6990 & 50 & 7705 & 7934 & (Domingo et al., 2010) \\
\hline GM & Valcervera & GrA-45783 & 6995 & 40 & 7727 & 7934 & (Montes et al., 2015) \\
\hline GM & Forcas II & Beta-290932 & 7000 & 40 & 7735 & 7935 & (Utrilla and Mazo, 2014) \\
\hline GM & Valcervera & GrA-45763 & 7035 & 45 & 7760 & 7960 & (Montes et al., 2015) \\
\hline GM & Costalena & MAMS-29828 & 7053 & 27 & 7838 & 7958 & Unpublished \\
\hline GM & Ángel 2 & Beta-286820 & 7120 & 50 & 7846 & 8021 & (Utrilla and Mazo, 2014) \\
\hline GM & $\begin{array}{l}\text { Cabezo de la } \\
\text { Cruz }\end{array}$ & GrN-29135 & 7150 & 70 & 7841 & 8160 & $\begin{array}{l}\text { (Rodanés and Picazo, } \\
\text { 2009) }\end{array}$ \\
\hline GM & Forcas II & Beta-250944 & 7150 & 40 & 7871 & 8031 & (Utrilla and Mazo, 2014) \\
\hline GM & $\begin{array}{l}\text { Rambla } \\
\text { Legunova }\end{array}$ & GrA-64001 & 7225 & 40 & 7966 & 8160 & (Montes et al., 2015) \\
\hline GM & $\begin{array}{l}\text { Rambla } \\
\text { Legunova }\end{array}$ & GrA-47886 & 7235 & 45 & 7970 & 8164 & (Montes et al., 2015) \\
\hline GM & Forcas II & GrN-22686 & 7240 & 40 & 7978 & 8163 & (Utrilla and Mazo, 2014) \\
\hline GM & \begin{tabular}{|l|} 
Rambla \\
Legunova
\end{tabular} & GrA-61768 & 7260 & 45 & 7983 & 8174 & (Montes et al., 2015) \\
\hline GM & Pontet & GrN-16313 & 7340 & 70 & 8012 & 8326 & $\begin{array}{l}\text { (Mazo and Montes, } \\
\text { 1992) }\end{array}$ \\
\hline GM & Pontet & D-AMS 020210 & 7341 & 32 & 8030 & 8283 & Unpublished \\
\hline GM & Baños & GrA-21550 & 7350 & 50 & 8028 & 8311 & $\begin{array}{l}\text { (Utrilla and Rodanés, } \\
\text { 2004) }\end{array}$ \\
\hline GM & Espantalobos & Beta-361624 & 7390 & 40 & 8055 & 8341 & (Montes et al., 2015) \\
\hline GM & Ángel 1 & GrA-27274 & 7435 & 45 & 8178 & 8357 & (Utrilla et al., 2009) \\
\hline GM & Baños & GrA-21551 & 7550 & 50 & 8206 & 8430 & $\begin{array}{l}\text { (Utrilla and Rodanés, } \\
\text { 2004) }\end{array}$ \\
\hline GM & Baños & GrN-24300 & 7570 & $\begin{array}{l}10 \\
0\end{array}$ & 8180 & 8560 & $\begin{array}{l}\text { (Utrilla and Rodanés, } \\
\text { 2004) }\end{array}$ \\
\hline GM & Botiquería & GrA-13265 & 7600 & 50 & 8335 & 8537 & $\begin{array}{l}\text { (Barandiarán and Cava, } \\
\text { 2000) }\end{array}$ \\
\hline GM & Esplugón & GrA-59632 & 7620 & 40 & 8365 & 8518 & (Utrilla et al., 2016) \\
\hline GM & Peña 14 & GrN-25094 & 7660 & 90 & 8224 & 8637 & (Montes et al., 2015) \\
\hline GM & Esplugón & GrA-59634 & 7715 & 45 & 8418 & 8584 & (Utrilla et al., 2016) \\
\hline DM & Baños & GrA-21552 & 7740 & 50 & 8420 & 8597 & $\begin{array}{l}\text { (Utrilla and Rodanés, } \\
2004 \text { ) }\end{array}$ \\
\hline DM & Baños & GrN-24299 & 7840 & $\begin{array}{l}10 \\
0\end{array}$ & 8445 & 8984 & $\begin{array}{l}\text { (Utrilla and Rodanés, } \\
\text { 2004) }\end{array}$ \\
\hline $\mathrm{DM}$ & Esplugón & Beta-306725 & 7860 & 40 & 8546 & 8933 & (Utrilla et al., 2016) \\
\hline$\overline{D M}$ & Espantalobos & Beta-361625 & 7900 & 50 & 8593 & 8978 & (Montes et al., 2015) \\
\hline $\mathrm{DM}$ & Pontet & D-AMS 020211 & 7941 & 65 & 8609 & 8030 & Unpublished \\
\hline $\mathrm{DM}$ & Ángel 1 & GrA-27278 & 7955 & 45 & 8647 & 8988 & (Utrilla et al., 2009) \\
\hline $\mathrm{DM}$ & Peña 14 & GrN-25998 & 8000 & 90 & 8598 & 9112 & (Montes et al., 2015) \\
\hline $\mathrm{DM}$ & Peña 14 & GrN-25999 & 8000 & 80 & 8605 & 9077 & (Montes et al., 2015) \\
\hline DM & Esplugón & GrA-59633 & 8015 & 45 & 8716 & 9020 & (Utrilla et al., 2016) \\
\hline $\mathrm{DM}$ & Baños & GrA-21556 & 8040 & 50 & 8719 & 9086 & $\begin{array}{l}\text { (Utrilla and Rodanés, } \\
\text { 2004) }\end{array}$ \\
\hline $\mathrm{DM}$ & Legunova & GrA-24292 & 8200 & 50 & 9015 & 9300 & (Montes et al., 2015) \\
\hline $\mathrm{DM}$ & Legunova & GrA-22086 & 8250 & 60 & 9032 & 9417 & (Montes et al., 2015) \\
\hline$\overline{D M}$ & Ángel 2 & GrA-22836 & 8310 & 60 & 9132 & 9466 & (Utrilla et al., 2009) \\
\hline $\mathrm{DM}$ & Esplugón & Beta 306722 & 8380 & 40 & 9299 & 9485 & (Utrilla et al., 2016) \\
\hline $\mathrm{DM}$ & Ángel 1 & GrA-22826 & 8390 & 60 & 9275 & 9526 & (Utrilla et al., 2009) \\
\hline DM & Forcas II & $\begin{array}{l}\text { Beta-59997/CAMS- } \\
5354\end{array}$ & 8650 & 70 & 9520 & 9887 & (Utrilla and Mazo, 2014) \\
\hline DM & Legunova & GrA-24294 & 8800 & 40 & 9666 & $\begin{array}{l}1013 \\
5\end{array}$ & (Montes et al., 2015) \\
\hline MLM & Forcas I & GrN-17785 & 9715 & 75 & $\begin{array}{l}1078 \\
5\end{array}$ & $\begin{array}{l}1125 \\
1\end{array}$ & (Utrilla and Mazo, 2014) \\
\hline MLM & Peña 14 & GrN-26000 & \begin{tabular}{l|}
1063 \\
0
\end{tabular} & $\begin{array}{l}10 \\
0\end{array}$ & $\begin{array}{l}1223 \\
7\end{array}$ & $\begin{array}{l}1273 \\
9\end{array}$ & (Montes et al., 2015) \\
\hline
\end{tabular}

Table 1. Radiocarbon dates of the Mesolithic sites (in alphabetic order) from the Middle Ebro Basin (GM: 
Geometric Mesolithic; DM: Denticulate Mesolithic; MLM: Microlaminar Mesolithic). 


\begin{tabular}{|c|c|c|c|c|c|c|}
\hline \multirow{2}{*}{ Site } & \multirow{2}{*}{ River basin } & \multirow{2}{*}{ Environmental area } & \multirow{2}{*}{$\begin{array}{c}\text { Altitud } \\
\text { e } \\
\text { asl }\end{array}$} & \multicolumn{2}{|c|}{$\begin{array}{l}\text { Distance closest } \\
\text { water course }(\mathrm{m})\end{array}$} & \multirow{2}{*}{$\begin{array}{c}\text { Orientatio } \\
n\end{array}$} \\
\hline & & & & $\begin{array}{l}\text { Horizont } \\
\text { al }\end{array}$ & $\begin{array}{l}\text { Vertic } \\
\text { al }\end{array}$ & \\
\hline Peña-14 & \multirow{4}{*}{ Arba de Biel } & \multirow{5}{*}{$\begin{array}{l}\text { Footsteps of middle } \\
\text { mountain ranges }\end{array}$} & 750 & 160 & 10 & $E$ \\
\hline Legunova & & & 700 & 5 & 2 & $\mathrm{E}$ \\
\hline Rambla & & & 695 & 70 & 5 & $E$ \\
\hline Valcervera & & & 655 & 70 & 5 & $E$ \\
\hline Esplugón & $\begin{array}{c}\text { Guarga } \\
\text { (Gállego) }\end{array}$ & & 805 & 300 & 20 & $\mathrm{~S}$ \\
\hline Espantalobos & $\begin{array}{l}\text { Flumen } \\
\text { (Cinca) }\end{array}$ & Dry lowlands & 500 & 850 & 20 & $E$ \\
\hline Forcas-I & \multirow{2}{*}{ Ésera (Cinca) } & \multirow{2}{*}{$\begin{array}{l}\text { Footsteps of middle } \\
\text { mountain ranges }\end{array}$} & 495 & 100 & 10 & W \\
\hline Forcas-II & & & 490 & 10 & 5 & $\mathrm{~N}$ \\
\hline Cabezo de la Cruz & Huerva & Dry lowlands & 428 & 300 & 20 & - \\
\hline Los Baños & Martín & Dry lowlands & 515 & 20 & 5 & $\mathrm{E}$ \\
\hline Ángel 1 & \multirow{3}{*}{ Guadalope } & \multirow{2}{*}{$\begin{array}{l}\text { Footsteps of middle } \\
\text { mountain ranges }\end{array}$} & 655 & 30 & 5 & $\mathrm{~W}$ \\
\hline Ángel 2 & & & 665 & 30 & 15 & SW \\
\hline Plano del Pulido & & \multirow{5}{*}{ Dry lowlands } & 240 & 1700 & 20 & $\mathrm{~S}$ \\
\hline Costalena & \multirow{4}{*}{$\begin{array}{l}\text { Matarraña/ } \\
\text { Algás }\end{array}$} & & 215 & 150 & 10 & $\mathrm{~S}$ \\
\hline $\begin{array}{l}\text { Botiquería dels } \\
\text { Moros }\end{array}$ & & & 330 & 40 & 10 & $E$ \\
\hline Pontet & & & 285 & 175 & 10 & W \\
\hline Secans & & & 360 & 150 & 10 & $\mathrm{E}$ \\
\hline
\end{tabular}

Table 2. Geographical features of the studied sites. Between parenthesis, main tributaries to the Ebro if the site is in a secondary river basin. 


\begin{tabular}{|c|c|c|c|c|}
\hline $\begin{array}{c}\text { Ebro River } \\
\text { Margin }\end{array}$ & $\begin{array}{c}\text { Hydrographical } \\
\text { basin }\end{array}$ & $\begin{array}{c}\text { Total } \\
\mathrm{km}^{2}\end{array}$ & Sites & $\mathrm{km}^{2} / \mathrm{site}$ \\
\hline \multirow{4}{*}{ Left/North } & Arba de Biel & 2,249 & 4 & 750 \\
\cline { 2 - 5 } & Guarga & 450 & 1 & 450 \\
\cline { 2 - 5 } & Flumen & 1,429 & 1 & 1,429 \\
\cline { 2 - 5 } & Ésera & 1,535 & 2 & 767 \\
\cline { 2 - 5 } & Subtotal left & 5,663 & 8 & 809 \\
\hline \multirow{4}{*}{ Right/South } & Huerva & 1,020 & 1 & 1,020 \\
\cline { 2 - 5 } & Martín & 2,095 & 1 & 2,095 \\
\cline { 2 - 5 } & Guadalope & 3,890 & 3 & 1,296 \\
\cline { 2 - 5 } & Matarraña/Algás & 1,250 & 4 & 312 \\
\cline { 2 - 5 } & Subtotal right & 8,255 & 9 & 917 \\
\hline Total & - & $\mathbf{1 3 , 9 1 8}$ & $\mathbf{1 7}$ & $\mathbf{8 7 0}$ \\
\hline
\end{tabular}

Table 3. The studied sites vs. the surface of the hydrographical basins where they are located. 


\begin{tabular}{|c|c|c|c|c|c|c|}
\hline $\begin{array}{c}\text { Site (level) } \\
\text { (period) }\end{array}$ & $\begin{array}{l}\text { Hearths } \\
\text { no. }\end{array}$ & $\begin{array}{c}\text { Surrounded } \\
\text { by blocks }\end{array}$ & $\begin{array}{c}\text { Non surrounded } \\
\text { by blocks }\end{array}$ & $\begin{array}{c}\text { Diameter (cm) } \\
\text { (average) }\end{array}$ & $\begin{array}{l}\text { Surface }\left(m^{2}\right) \\
\text { (average) }\end{array}$ & $\begin{array}{c}\text { Blocks } \\
\text { no. } \\
\text { (average) }\end{array}$ \\
\hline $\begin{array}{l}\text { Ángel } 2 \text { (2b) } \\
\text { (DM) }\end{array}$ & 1 & 1 & - & 140 & 1,54 & 11 \\
\hline $\begin{array}{l}\text { Botiquería (2) } \\
\text { (GM) }\end{array}$ & 2 & 2 & - & No data & No data & 7 \\
\hline $\begin{array}{l}\text { Botiquería (4) } \\
\text { (GM) }\end{array}$ & 8 & 5 & 3 & No data & No data & 7 \\
\hline $\begin{array}{l}\text { Cabezo de la } \\
\text { Cruz (GM) }\end{array}$ & 1 & - & 1 & 65 & 0,38 & - \\
\hline $\begin{array}{l}\text { Costalena (c } \\
\text { gener) (GM) }\end{array}$ & 1 & 1 & - & 110 & 1,1 & No data \\
\hline $\begin{array}{l}\text { Costalena (c } \\
\text { sup) }(\mathrm{GM})\end{array}$ & 3 & 3 & - & No data & 0,44 & No data \\
\hline $\begin{array}{l}\text { Costalena (c3) } \\
(\mathrm{GM})\end{array}$ & 7 & 7 & - & No data & 0,18 & No data \\
\hline $\begin{array}{l}\text { Espantalobos (e } \\
\text { - c) (DM-GM) }\end{array}$ & 6 & 3 & 3 & No data & No data & No data \\
\hline $\begin{array}{l}\text { Forcas I (7) } \\
\text { (MLM) }\end{array}$ & 1 & 1 & - & No data & No data & No data \\
\hline $\begin{array}{l}\text { Forcas II (Ib) } \\
\text { (DM) }\end{array}$ & 2 & 1 & 1 & 85 & 0,55 & 1 \\
\hline $\begin{array}{l}\text { Forcas II (II) } \\
(\mathrm{GM})\end{array}$ & 2 & 2 & - & No data & No data & No data \\
\hline $\begin{array}{l}\text { Forcas II (IV) } \\
(\mathrm{GM})\end{array}$ & 4 & 2 & 2 & 37 & 0,1 & No data \\
\hline $\begin{array}{l}\text { Peña-14 (b) } \\
\text { (DM) }\end{array}$ & 2 & 2 & - & 50 & 0,20 & 8 \\
\hline Pontet (e) (GM) & 3 & - & 3 & No data & No data & - \\
\hline Rambla (2) (GM) & 1 & 1 & - & 60 & 0,28 & 10 \\
\hline
\end{tabular}

Table 4. Available data of Mesolithic hearths from the Ebro Basin sites (in alphabetical order); MLM:

Microlaminar Mesolithic; DM: Denticulate Mesolithic; GM: Geometric Mesolithic. 